\title{
한국판 칼레이도스코프 경력태도 측정도구 타당화 연구*
}

\author{
이 재 은 \\ 상지대학교 \\ 정 보 영 $^{+}$ \\ 현대자동차
}

\begin{abstract}
이 연구의 목적은 Sullivan과 그의 동료들(2009)이 개발한 칼레이도스코프 경력태도 척도를 우 리나라의 기업근로자 대상으로 타당화하는 데 있다. 이를 위해 수정델파이법을 통해 내용타 당도를 검증하고, 남녀 기업근로자를 대상으로 2 개의 표본자료를 수집하여 $(\mathrm{N}=347, \mathrm{~N}=631)$ 구인타당도, 변별타당도, 준거타당도를 검증하였다. 연구결과는 다음과 같다. 첫째, 수정델파 이법을 통해 번안된 칼레이도스코프 경력태도 측정문항의 내용타당도를 확인하고 국내 기업 근로자에게 적용할 수 있는 3 문항을 개발하였다. 둘째, 칼레이도스코프 경력태도 측정문항은 원척도와 같이 3 개 요인으로 구성되었으며, 최종 13 개 문항으로 구성된 측정도구의 적합도 가 적절하게 도출되어 이를 채택하였다. 셋째, 교차타당도 분석 결과 새로운 표본 $(\mathrm{N}=631)$ 에 서 13 개 문항의 측정모형 적합도가 양호하였으며 남녀 성별 집단에서도 동일한 척도로 활용 될 수 있음을 확인하였다. 한편, 칼레이도스코프 경력태도 중 균형과 도전 인식에서 성별 집 단의 잠재평균 차이가 유의한 것으로 나타났다. 연구결과를 종합하여 한국판 칼레이도스코 프 경력태도가 타당하고 신뢰할 수 있는 척도임을 밝혔으며, 이를 토대로 연구의 의의와 한 계점, 향후 연구를 위한 제언 등이 논의되었다.
\end{abstract}

주요어 : 칼레이도스코프 경력, 만화경 경력, 측정도구, 타당화, 잠재평균분석

* 이 논문은 2019년 대한민국 교육부와 한국연구재단의 인문사회분야 신진연구자지원사업의 지원을 받아 수행된 연구임(NRF-2019S1A5A8038225).

† 교신저자 : 정보영, 현대자동차 인재개발팀 책임매니저, viautumn@gmail.com 
최근 많은 근로자들이 경험하고 있는 급격 한 환경변화는 개인의 경력에 대한 태도와 경 력개발의 기준을 모두 바꾸어 놓고 있다. 조 직 중심의 경력개발에서 개인 주도의 경력개 발로 구심점이 이동한 경력 패러다임의 변화 는 더 이상 새로운 관점이 아닌 것으로 여겨 지고 있다. 조직 구성원들의 경력에 관한 태 도와 경력개발 의사결정 등과 관련하여 새로 운 개념 제시와 관점 채택이 필요한 시점이다. 이러한 경력 패러다임의 변화와 함께 국내외 경력 연구자들은 새로운 경력태도에 관심을 갖고 연구해 왔다. 새로운 경력태도와 관련하 여 프로티언 경력(protean career), 무경계 경력 (boundaryless career)과 함께 자주 거론되는 모 형이 Mainiero와 Sullivan(2005)이 제안한 칼레이 도스코프 경력모형(Kaleidoscope Career Model: KCM)으로(Baruch, 2007; Sullivan \& Baruch, 2009), 국내에서는 만화경 경력모형, 또는 만 화경 경력태도로 번안되기도 하였다. Mainiero 와 Sullivan(2005)은 환경변화에 따라 기존의 경력 개념에 변화가 필요하다고 설명하면서, 만화경이 반사에 의해 무한한 패턴을 만드는 것과 같이 개인은 경력과 관련하여 3 개의 주 요한 경력 파라미터(career parameter: 진정성 (authenticity), 균형(balance), 도전(challenge))를 회 전시키며 다양한 경력 패턴을 만들어 간다고 보았다. 즉 개인은 자신의 생애 경력발달 단 계에서 나타날 수 있는 정체성 갈등을 해결해 나가면서 경력 발전의 중요한 축이 되는 경력 파라미터를 개인의 정체성에 맞게 조정하며 경력과 관련된 의사결정을 수행해간다는 것이 다(Kirk, 2016). 칼레이도스코프 경력모형은 삶 의 전체적인 맥락 안에서 구성주의적 관점을 갖고 개인의 경력개발에 초점을 두어야 한다 는 최근 경력 관련 연구자들의 주장을 수용하
고 있다(McMahon, 2014; Savickas, 2012). 그러나 국내 뿐 아니라 국외에서도 칼레이도스코프 경력에 대한 연구는 아직까지 크게 확산되지 못하고 있는 실정이다. 이는 칼레이도스코프 경력이 특정 시점에서의 근로자 경력태도를 확인하고 이와 관련된 다양한 변인이 무엇인 지 밝히는 것에 초점을 두고 있기 보다는 근 로자의 생애에 걸친 경력패턴의 변화를 설명 하는 것을 목적으로 하고 있기 때문이라 짐작 된다.

선행연구에서 칼레이도스코프 경력태도는 주로 특정 집단의 경력에 대한 태도를 이해하 거나 경력 관련 행동에 차이가 있는 두 집단 의 특성을 비교할 목적으로 활용되어 왔다. 예를 들어, 여성(August, 2011; Cabrera, 2007; Shaw \& Leberman, 2015), 기업가(Sullivan, Forret, Mainiero, \& Terjesen, 2007), 교원(Carraher, Crocitto \& Sullivan, 2014)의 칼레이도스코프 경 력태도를 구명하고자 한 연구가 수행되었으며, 성차(Mainiero \& Gibson, 2018)나 세대차(Sullivan, Forret, Carraher, \& Mainiero, 2009)를 밝히고자 한 연구들이 있었다. Sullivan과 Baruch(2009)는 개인의 경력 관련 의사결정에 있어 진정성, 균형, 도전의 속성이 점점 더 중요해지고 있 다고 설명하였으나, 서구 문화권에서 다양한 집단을 대상으로 칼레이도스코프 경력모형이 적용되어 온 것과 달리 국내 근로자를 대상으 로 칼레이도스코프 경력태도를 측정하거나 칼레이도스코프 경력모형을 적용한 연구는 매우 부족한 실정이다. 이에 우리나라 근로 자에게도 칼레이도스코프 경력을 구성하는 세 개의 경력 파라미터가 유효한지 검증할 필요가 있다.

경력 패러다임의 변화와 함께 나타난 근로 자의 새로운 경력태도를 대표하는 프로티언 
경력태도는 주도적으로 자신의 가치에 기초하 여 경력을 개발하는 개인의 태도(Hall, 2004)로 자기주도적 경력관리와 개인가치 지향이라는 두 가지 하위요인으로 구성된다. 많은 연구에 서 프로티언 경력태도는 고용가능성, 주관적 경력성공, 경력만족, 직무만족, 조직몰입 등 개인의 긍정적인 경력, 조직 태도와 정적으로 관련되어 있어(Lee, Park, \& Kim, 2019), 프로티 언 경력이 새로운 경력 패러다임 시대에 적응 적인 경력태도임을 밝힌 바 있다. 이 연구의 주요 관심인 칼레이도스코프 경력태도는 프로 티언 경력태도에서 강조하고 있는 '개인 가치 지향'의 실체를 보다 상세하게 설명해 준다는 측면에서 의의가 있다. 칼레이도스코프 경력 에서 강조하고 있는 세 가지 경력 파라미터가 개인이 지향하는 구체적인 가치가 될 수 있기 때문이다. 칼레이도스코프 경력은 '현대사회에 서 경력과 관련하여 개인이 추구하는 가치는 무엇인가?', '이러한 가치는 전체 경력개발의 단계에서 어떻게 달라지는가?', '개인의 경력 과 관련하여 변화된 가치는 경력관련 태도와 행동에 어떠한 영향을 미치는가?' 등의 질문에 답변을 가능하게 한다.

칼레이도스코프 경력태도에서 강조하고 있 는 도전, 진정성, 일과 삶의 균형 등은 최근 일터에서의 경험, 리더십, 일-가정 균형 등 구 성원들의 일과 관련된 태도에서 중요한 가치 로 다루어지고 있다. 따라서 칼레이도스코프 경력태도가 높은 근로자일수록 보다 효과적인 경력 관련 태도 및 행동을 보일 가능성이 높 을 것으로 판단된다(Kim \& Lee, 2020). 이 연구 에서는 칼레이도스코프 경력태도의 응답값이 경력 관련 긍정적인 태도 및 행동과 유의한 관계를 갖는지 검증하고자 한다. 이를 통해 칼레이도스코프 경력태도의 크기가 갖는 의미
를 확인할 수 있을 것이다.

이 연구는 우리나라 기업근로자를 대상으로 하여 칼레이도스코프 경력태도 측정도구를 타당화하는 것을 목적으로 한다. 이를 위해 Sullivan, Forret, Carraher와 Mainiero(2009)가 개발 한 칼레이도스코프 경력태도 측정도구를 번안 하여 내용타당도를 확인하고, 탐색적 요인분 석과 확인적 요인분석을 통해 구성개념 타당 도를 검증하고자 한다. 또한 칼레이도스코프 경력태도의 구성개념과 관련된 일과 삶의 균 형, 프로티언 경력태도, 도전적 직무행동, 경 력만족, 고용가능성, 경력몰입 등의 변인과의 관계를 분석하여 준거관련 타당도를 확인하고 자 한다. 이를 통해 향후 칼레이도스코프 경 력태도 관련 연구의 방향을 제시하고자 한다.

\section{이론적 배경}

\section{칼레이도스코프 경력모형}

칼레이도스코프 경력모형은 처음 제안된 당 시 여성의 경력경로 발달의 특징을 깊이 조명 하고자 하였다. 특히 기존의 전통적인 경력 경로가 아닌 새로운 경력 패러다임을 강조하 면서 경력과 관련된 남녀의 차이를 주요하게 다루었다. Mainiero와 Sullivan(2006)은 남성의 경 우 하나 혹은 두 개의 조직에서 일하는 경우 뿐만 아니라 다양한 조직을 거치더라도 상향 이동을 지향하는 전통적인 경력패턴을 갖는 반면, 대다수 여성들의 경력이동은 비선형적 이며 노동시장을 떠났다가 재진입하는 등 이 동을 반복하는 경향을 갖고 있다고 강조하면 서 칼레이도스코프 경력모형을 통해 여성의 경력 의사결정을 설명할 수 있다고 하였다. 
칼레이도스코프 경력모형 $(\mathrm{KCM})$ 은 세 개의 평면거울이 반사에 의해 무한한 패턴을 만드 는 것과 같이 개인이 경력 관련 의사결정을 내릴 때, 세 개의 주요 경력 파라미터(career parameter)를 회전시키며 다양한 경력 패턴을 만들어간다고 설명한다. 세 개의 파라미터는 진정성(authenticity), 균형(balance), 도전(challenge) 으로 구성되며, 진정성은 진정한 자기 자신이 되는 것으로, 균형은 일(work)과 일 외적인 요 구 사이의 균형으로, 도전은 개인을 자극하는 일과 경력에서의 발전으로 정의된다. 이러한 세 개의 파라미터는 생애주기 동안 모두 활성 화되어 있으나, 특정 시기에 어떤 파라미터가 강하게 나타나는가에 따라 개인의 경력 패턴 이 결정되게 된다. 보다 구체적으로 개인은 경력 파라미터에 기반하여 직무요구, 제한, 기 회와 개인이 얻게 될 가치, 이익, 관계 등을 비교하며 최적의 상태(best fit)를 추구한다는 것이다. 즉 개인의 생애에 걸친 경력 의사결 정과 그 결과로 나타나는 경력패턴을 경력 파 라미터를 중심으로 이해할 수 있다는 데 모형 의 의의가 있다.

\section{칼레이도스코프 경력태도의 측정}

경력태도(career attitude)는 경력에 대한 신념, 지식, 사고 등 인지적 요소와 선호되는 경력 인지 아닌지에 대한 평가적 요소 또는 정서적 요소, 특정 방향으로 행동하려는 행동 의도 및 경향에 해당하는 행동적 요소를 포괄하는 개념이다. 태도는 다양한 환경에 의해 학습되 고, 특정한 행동을 유발하며, 특정한 사물, 사 건에 대해 일관된 선호 또는 비선호를 갖게 하는 특징이 있다(Fishbein \& Ajzen, 1975). 또한, 태도는 가변적 속성을 갖고 있어 개인의 경험,
환경, 맥락적 상황에 따라 변화한다. 경력태도 는 개인의 경력과 관련된 특정한 행동을 예측 하는 변인으로 다루어져 왔으며, 주요 연구도 경력태도의 결과변인에 초점을 맞추어 이루 어져왔다. 선행연구에서는 주로 전통적 경력 태도(traditional career attitude), 프로티언 경력 태도(protean career attitude), 무경계 경력태도 (boundaryless career attitude) 등 경력과 관련된 특정한 관점을 강조해 왔다. 이 연구에서는 칼레이도스코프 경력모형에서 제시된 칼레이 도스코프 경력태도에 초점을 맞추고 경력태도 를 설명하고자 한다.

칼레이도스코프 경력태도는 Sullivan과 그의 동료들(2009)이 개발한 측정도구를 통해 측정 할 수 있다. 칼레이도스코프 경력 측정도구는 세 개의 하위요인과 15 문항으로 구성되어 있 으며, (1) 나를 전혀 표현하지 못하고 있다 부 터 (5) 나를 매우 잘 표현하고 있다 까지 자기 보고식 5점 LIkert 척도로 측정하게 된다. Sullivan과 그의 동료들(2009)의 연구는 칼레이 도스코프 경력태도의 세대 간 차이를 확인하 기 위한 목적으로 실시되었는데, 칼레이도스 코프 경력태도 측정도구의 구인타당도는 보고 되지 않았다. 다만 각 경력파라미터의 내적 일치도는 진정성 .76 , 균형 .81 , 도전 .84 로 보 고되었다. 또한 경력 파라미터 간 상관관계의 범위는 .48-.56으로 중간 정도의 상관을 보였 다. 이 연구에서는 세대차 외에도 통제변인으 로 성별, 자녀 수, 혼인상태, 교육수준, 소득과 칼레이도스코프 경력의 상관관계도 분석하였 는데 남성에 비해 여성이 진정성(.14)과 균형 (.08)에서 유의한 정적 상관관계를 보였고, 자 녀 수와 진정성(.08), 균형(.27), 도전(.07) 간 상 관관계가 유의하였으며, 기혼일 때 균형(.18)과 의 상관관계가 유의하였다. 또한, 교육수준과 
진정성(.07), 도전(.10) 간 상관관계가 유의하였 으며, 소득수준은 균형(.07)과 도전(.11) 간 상 관관계가 유의한 것으로 보고되었다.

한편, 최근 수행된 Kim과 Lee(2020)의 연구 에서 칼레이도스코프 경력태도를 측정하고 구 인타당도를 확인하였다. 이 연구는 Mainiero와 Gibson(2017)의 16문항으로 구성된 칼레이도스 코프 측정도구를 활용하였는데, 탐색적 요인 분석 과정에서 도전과 균형의 측정 문항이 부 적으로 할당되어 선행연구에서 제시하고 있는 칼레이도스코프 경력태도의 요인 구조를 확인 하는 데 한계가 있었다. 정량적 접근만 활용 했을 때 나타나는 이러한 한계점을 극복하기 위해, 이 연구는 델파이 조사를 실시하여 칼 레이도스코프 측정도구 번안 내용을 검토하고 국내 근로자들의 경력개발 환경에 적용할 수 있는 문항을 새롭게 추가하고자 하였다.

\section{칼레이도스코프 경력태도 관련 선행연구}

Mainiero와 Sullivan(2005)이 처음으로 칼레이 도스코프 경력모형을 제안한 이후 이를 기반 으로 한 양적, 질적 연구와 이론 연구들이 다 수 수행되어 왔다. 특히 후속연구들은 세 개 의 경력 파라미터가 실제로 존재하는 지에 대 한 근거를 제시하였는데, Sullivan과 그의 동료 들(2009)은 928명을 대상으로 칼레이도스코프 경력태도가 타당하게 구분될 수 있음을 밝혔 으며, Cabrera(2007)는 497명의 전문직 여성을 대상으로 한 연구에서 $62 \%$ 의 응답자가 자신 의 경력에 대한 초점이 시간에 따라 변화되었 다고 기술하였음을 설명하였다. 또한 Baruch와 그의 동료들(2014)은 칼레이도스코프 경력모형 과 계획행동이론에 따라 교원의 연구년에 대 한 의사결정을 설명하는 모델을 제안하였다.
Shaw와 Leberman(2015)은 뉴질랜드의 여성 CEO 7명을 대상으로 한 심층 인터뷰를 통해 경력 파라미터의 하위 주제를 확인하여 칼레이도 스코프 경력모형을 확장하였는데, 구체적으로 진정성에는 열정과 관계구축이, 균형에는 자 기인식과 조직 내 영향이, 도전에는 기회수용 과 남성중심 환경에서의 업무수행이 도출되 었다.

한편 칼레이도스코프 경력태도의 세 가지 경력 파라미터에 대한 태도를 각각 비교하여 성차나 세대차와 같이 집단 간 차이가 있음을 밝히는 데 초점을 둔 연구들도 수행되었다. 먼저 성차와 관련된 연구를 살펴보면, Sullivan 과 Mainiero(2007)는 응답자 중 대부분(84\%)의 남성들은 초기-중기-말기의 경력단계에서 도전 -진정성-균형에 각각 순서대로 초점을 두는 알 파 칼레이도스코프 경력 패턴을 갖고 있는 반 면, 대부분의 여성(83\%)들은 초기에는 도전, 중기에는 균형, 말기에는 진정성에 초점을 두 는 베타 칼레이도스코프 경력 패턴을 보였다 고 설명하였다. Cabrera(2009)도 25명의 여성을 심층 인터뷰한 질적 연구를 통해 베타 경력 패턴이 여성에게 있어서 가장 많이 나타나 는 패턴임을 밝혔다. 최근 수행된 Mainiero와 Gibson(2017)의 연구에서는 경력중기의 남녀 실업자를 대상으로 칼레이도스코프 경력태도 의 차이를 밝혔는데, 여성은 남성에 비해 균 형을 훨씬 중요하게 생각하고 있었으며, 경력 후기로 갈수록 남녀 모두 진정성을 더 강조 하는 것으로 나타났다. Elley-Brown, Pringle과 Harris(2018)가 교육분야 뉴질랜드 여성 직업인 을 대상으로 한 연구에서는 경력 중기 여성에 게서 알파 경력에 대한 선호가 관찰되었으며, 진정성은 여성에게 여전히 중요한 파라미터임 을 밝혔다. 
칼레이도스코프 경력모형을 적용한 세대차 연구도 수행되었다. Sullivan과 그의 동료들 (2009)은 X세대의 경우 베이비부머 세대에 비 해 진정성과 균형에 대한 높은 요구를 갖고 있는 것으로 나타났으나 도전에 대한 세대 차는 발견되지 않았다고 설명하였다. August (2011)는 경력후기 여성을 대상으로 질적 연구 를 수행한 결과 여성은 상대적으로 젊을 때 도전을 더 강조하는 것으로 나타났으며, 경력 후기로 갈수록 진정성과 균형을 강조하고 있 다고 설명하였다.

칼레이도스코프 경력태도와 관련된 선행연 구를 종합해보면, 칼레이도스코프 경력모형이 제안된 이후 새로운 기업 환경에서의 경력을 설명하기에 칼레이도스코프 경력 모형이 적절 한 지에 대한 연구와 경력과 관련된 태도에서 의 성차, 세대차를 칼레이도스코프 경력모형 으로 설명할 수 있는지에 초점을 맞추고 연구 들이 수행되어 온 것을 알 수 있다. 특히 여 성의 생애사건과 경력단계에 따른 경력 파라 미터의 변화를 분석한 질적 연구들이 많이 수 행되었다. 그러나 다음과 같은 한계점이 관찰 된다. 첫째, 칼레이도스코프 경력태도의 측정 도구가 여러 문화에 걸쳐 타당한지 측정도구 를 타당화 한 연구는 찾아보기 어렵다. 둘째, 칼레이도스코프 경력모형이 현대인의 경력 태 도를 설명하는데 타당한 지 확인하기 위해 특 정 집단을 대상으로 한 질적 연구 방법에 초 점을 두고 있어 다양한 대상을 포괄한 양적 연구의 수행이 요구된다. 셋째, 칼레이도스코 프 경력태도의 성차와 관련하여 여성이 알파 경력패턴을 갖는다는 결과와 베타 경력패턴을 갖는다는 상반된 연구결과가 존재하므로 보다 다양한 맥락적 변인을 종합적으로 고려한 연 구설계가 필요하다. 마지막으로 칼레이도스코
프 경력태도의 성별, 세대별 집단 간 차이를 다룬 연구에서도 칼레이도스코프 경력태도의 각 경력 파라미터의 평균 차이를 분석하고 있 다. 이는 각 집단에서의 동일한 측정을 가정 한다. 그러나 실제로 이러한 집단 간에(예. 남 성 vs. 여성) 칼레이도스코프 경력에 대한 측 정동일성이 검증되지 않았다는 점에서 한계가 있다.

\section{칼레이도스코프 경력태도와 성차}

칼레이도스코프 경력모형은 남성과 다른 여 성의 경력태도를 제안하기 위한 목적으로 처 음 발표되었으므로 칼레이도스코프 경력태도 의 성차는 선행연구에서 중요하게 다루어져 왔다. 그러나 칼레이도스코프 경력태도의 차 이를 실증적으로 검증한 연구는 제한적으로 수행되었다. 예를 들어 Mainiero와 Gibson(2017) 은 미국의 남녀 경력 중기 실업자 $(\mathrm{N}=744)$ 를 대상으로 칼레이도스코프 경력태도의 성차를 검증하였는데, 경력중기 여성은 남성보다 균 형을 더 강조하는 것을 밝혔다.

칼레이도스코프 경력태도를 활용하여 성별 차이를 밝힌 연구는 제한적이나 직업가치나 경력성공에 대한 준거에 대한 연구를 통해 칼 레이도스코프 경력태도의 성차를 유추할 수 있다. 예를 들어, Parker와 Chusmir(1992)는 경 력성공의 준거를 성별에 따라 비교하였는데, 여성은 남성에 비해 가족관계, 개인적 성취, 직업안정성 등을 중요하게 생각하고 지위 에 대한 중요성은 낮게 평가하였다. Dyke와 Murphy(2006)의 연구에서는 여성은 남성에 비 해 균형과 관계를 중요한 직업적 성공으로 여기고 있었다. 국내 연구에서는 $\mathrm{Kim}$ 과 $\mathrm{Cha}$ (2014)가 성별에 따라 경력성공 준거에 대한 인식에 차이가 있음을 밝혔는데, 여성은 남성 
에 비해 경제적 안정, 일과 삶의 균형, 평생 직장, 행복/즐거움 등을 더 중요하게 인식하 는 것으로 나타났다. 일반적으로 여성의 경 우 출산과 육아 뿐 아니라 생애단계에 따라 주어지는 돌봄 노동에 대한 기대로 균형에 대한 가치를 중요하게 생각할 것으로 가정할 수 있다.

가설 1. 여성은 남성에 비해 칼레이도스코 프 경력태도 중 균형에 대한 인식이 유의미하 게 높을 것이다.

\section{칼레이도스코프 경력태도와 프로티언 경력 태도, 일-삶의 균형, 도전적 직무경험}

프로티언 경력태도는 경력에 대한 새로운 사고방식으로 '개인적인 가치를 토대로 경력 을 선택하는 자기주도적이고 자유의지를 반영 한 경력 관련 태도'를 말한다(Briscoe \& Hall, 2006, p.6). 즉 프로티언 경력태도는 환경의 변 화 뿐 아니라 개인이 갖고 있는 가치에 따라 자신의 경력을 주도적으로 개발하고 관리하는 것이다(Hall, 2004). 프로티언 경력태도는 크게 두 가지 하위요인으로 구성되는데, 자기주도 적 경력관리 태도(self-directed career management attitude)와 가치기반 경력태도(value-driven career attitude)로 나눌 수 있다(Briscoe, Hall, \& DeMuth, 2006). 자기주도적 경력관리 태도는 스스로 경력관리의 주체가 되어 주도적인 역 할을 수행하는 것을 의미하며, 가치기반 경력 태도는 외적 보상보다는 개인의 고유한 가치 에 기반하여 심리적 성공을 추구하는 정도를 의미한다(Briscoe \& Hall, 2006). 프로티언 경력 태도의 두 가지 하위요인은 칼레이도스코프 경력태도의 하위요인 중 진정성 파라미터와 유사하다. 진정성은 '나 자신에게 진실한 것 (true to oneself)'으로 일터에서의 삶, 또는 자기 자신을 진정한 나로 받아들일 수 있는지와 관 련된다(Mainiero \& Sullivan, 2005). 이는 개인의 내적 가치와 연관되어 있을 것이라 가정할 수 있으며, 실제로 여성을 대상으로 한 질적 연 구에서 진정성을 유지하기 위해서는 개인의 가치와 조직의 가치를 정렬하는 것이 중요하 다는 것을 발견하였다(Shaw \& Leberman, 2015). 따라서 칼레이도스코프 경력태도의 진정성 파 라미터는 프로티언 경력태도와 유의한 상관관 계를 가질 것이라 가정하였다.

가설 2. 칼레이도스코프 경력태도는 프로티 언 경력태도와 유의한 정적 상관관계를 가질 것이다.

일-삶의 균형(work-life balance: WLB)은 근로 자가 일 영역과 삶의 영역 간 균형을 이루기 위해 개인적 자원을 필요한 역할 영역에 적 절하게 배분하는 것을 의미한다(Lee \& Choi, 2019). Kim과 Park(2008)은 개인적 자원에는 시 간, 심리적 에너지, 신체적 에너지 등이 있을 수 있으며, 적절한 분배를 통해 삶에 대한 통 제감을 갖고 삶에 만족한 상태를 의미한다고 설명하였다. 칼레이도스코프 경력태도의 하위 요인 중 균형 파라미터는 개인의 일과 삶에 있어서 균형을 유지하는 것이 얼마나 중요한 지에 대한 개인의 인식을 반영한다(Mainiero \& Sullivan, 2005). 실제로 선행연구에서 혼인여부 와 자녀의 수는 칼레이도스코프 경력태도 중 균형과 유의한 상관관계를 갖는 것으로 나타 났으며, 이러한 경력 파라미터를 중요하게 생 각하는 근로자는 실제 일-삶의 균형을 높게 유지할 것이라 가정할 수 있다. 
가설 3. 칼레이도스코프 경력태도는 일-삶의 균형과 유의한 정적 상관관계를 가질 것이다.

도전적 직무경험은 현재 일상적으로 사용 하고 있는 업무수행 전략이나 방식이 불충분 하여 과업을 수행하는 새로운 방법이 요구되 는 업무활동을 의미한다(Lee \& Cho, 2019). 도 전적 직무경험은 개인으로 하여금 새로운 학 습의 기회나 동기를 제공해주는 직무 특성을 포함하고 있고(McCauley, Ruderman, Ohlott, \& Morrow, 1994), 이를 통해 개인은 지식, 기술, 능력, 통찰력, 가치 등을 개발하여 성장할 수 있게 된다. 칼레이도스코프의 도전 파라미터 는 개인이 지속적으로 학습할 수 있는 긍정적 이고 도전적인 환경을 구축하는 것과 관련된 다(Shaw \& Leberman, 2015). 도전은 개인이 업 무로부터 오는 책임을 두려워하지 않고, 새로 운 일에서 성장의 기회를 발견하는 것을 의미 한다(Sullivan et al., 2009). 따라서 칼레이도스코 프 경력태도 중 도전 파라미터는 도전적 직무 경험과 높은 상관관계를 가질 것이라 가정할 수 있다.

가설 4. 칼레이도스코프 경력태도는 도전적 직무경험과 유의한 정적 상관관계를 가질 것 이다.

\section{칼레이도스코프 경력태도와 경력몰입, 주관 적 경력성공}

경력몰입은 자신의 직업에 대한 일반적 태 도 중 하나로 개인이 선택한 직업에서 지속적 으로 일하고자 하는 동기이다(Blau, 1985). 경 력몰입은 자신의 직무에 대한 개인의 동일시 나 현재의 경력목표를 추구해 나가는 과정에 서 어려움을 감수할 수 있는 의지로써 정서적,
심리적 과정 또는 결과로 설명되기도 한다 (Aryee \& Tan, 1992). 경력몰입은 몰입 대상에 대한 심리적 애착이라는 관점에서 직무몰입 및 조직몰입과 유사하지만, 몰입의 대상이 조 직이 아니라 개인의 내재적인 경력 목표라는 관점에서, 그리고 특정 시점이 아닌 장기적인 속성을 갖는다는 점에서 차이가 있다(Cho \& Lee, 2017). 개인의 경력몰입은 현재의 경력을 지속적으로 유지하고자 하는 동기를 나타내므 로 많은 연구에서 경력 적응의 지표로 활용되 어 왔다.

주관적 경력성공은 개인의 경력과 관련된 성취나 만족감이라고 정의되며, 현재 직무를 포함한 개인의 모든 경력에서의 성공에 대 한 주관적 평가로 정의된다(Seibert, Crant, \& Kraimer, 1999). 주관적 경력성공을 연구한 많 은 선행연구들은 경력만족을 주관적 경력성공 의 지표로 측정해 왔으며(Gattiker \& Larwood, 1986; Judge, Cable, Boudreau, \& Bretz, 1995), 최 근에는 경력에 대한 주관적 만족감 외에 개인 의 지속적인 고용가능성에 대한 인식을 주관 적 경력성공의 하위요인으로 포함해 왔다(Lee \& Lee, 2016). 개인이 자신의 경력에 대해 긍정 적으로 평가하고 인식하는 것과 관련된 주관 적 경력성공은 개인의 경력 결과에 대한 주관 적인 판단으로 많은 선행연구에서 경력개발 노력에 대한 결과변인으로 다루어져 왔다(Kim \& Moon, 2018).

한편, Lee(2018)는 X세대와 Y세대의 경력성 공 준거에 대한 인식을 비교하면서 즐거움, 균형, 도전과 같은 내부 지향의 주관적인 준 거들을 포함시켰으며 $\mathrm{Y}$ 세대의 경력성공 인식 프로파일을 분석하고 개인의 경력성공 중요도 및 성취도 인식 수준을 비교한 바 있다. 이 연구에서 $\mathrm{Y}$ 세대의 경력성공 인식의 잠재유형 
중 즐거움과 균형을 중요하게 생각하는 유형 과 도전과 기여를 중요하게 생각하는 유형이 있었는데, 두 가지 유형은 다른 유형(지위와 도전 중심 유형, 보상과 안정 중심 유형)에 비 해 경력만족이 더 높은 것으로 나타났다. 즐 거움, 균형, 도전과 같은 경력성공의 준거가 칼레이도스코프 경력태도의 진정성, 균형, 도 전과 유사한 개념이라고 가정하면, 칼레이도 스코프 경력태도의 각 하위요인의 값이 높은 것이 보다 적응적인 것을 의미하는 것으로 해 석할 수 있을 것이다. 따라서 이 연구에서는 칼레이도스코프 경력태도의 하위요인의 수준 이 높은 것은 주관적 경력성공 그리고 경력몰 입과 유의미한 정적 상관관계를 가질 것이라 가정하였다.

가설 5. 칼레이도스코프 경력태도는 경력몰 입과 유의한 정적 상관관계를 가질 것이다.

가설 6. 칼레이도스코프 경력태도는 주관적 경력성공과 유의한 정적 상관관계를 가질 것 이다.

\section{연구 1. 내용타당도 분석}

선행연구 검토를 통해 한국형 칼레이도스코 프 경력태도를 측정하는 데 있어 Sullivan과 그 의 동료들(2009)의 도구가 가장 근접한 조사도 구라는 연구자 간 합의를 도출하고, 해당 도 구를 번역-역번역법을 통해 국문화한 뒤, 수 정델파이법을 활용하여 전문가들의 의견을 취 합함으로써 측정도구 초안을 개발하였다.

\section{연구방법}

첫째, 번역된 도구의 심리측정적 등가성 (psychometric equivalence)을 확보하기 위해 번역 -역번역법(back-translation method)을 실시하였다 (Brislin, 1973). 번역-역번역법은 번역문의 정확 도를 교차검증하기 위해 목표어로 번역된 도 구를 다른 사람에 의해 원어(source language)로 다시 번역하여 원래의 도구와 역번역된 도구 를 비교하는 것이다. 이에 연구자는 측정도구 원문을 개발한 주저자 Sullivan의 동의를 얻어, Sullivan과 그의 동료들(2009)이 제시한 칼레이 도스코프 경력태도 세 개 요인 15 문항을 번역 -역번역 하였다. 최초 번역은 연구자 2 인이 합의를 통해 실시하였다. 역번역 과정에서 미 국에서 10 년 이상 거주하고 $\mathrm{HRD}$ 석사 학위 를 취득하여 한국어와 영어 모두 능숙한 이중 언어 구사자(bilingual) 1 명에게 연구 도구에 대 한 배경설명 없이 도구를 역번역 하도록 하였 다. 대표적으로 진정성 파라미터의 5 문항 중 하나로 지금 당장 내 꿈을 따라갈 수 있다면, 나는 그렇게 할 것이다.'는 'If I can follow my dream right now, I will'로 번역되었고, 균형 파라 미터 5 문항 중 하나인 일과 가정의 균형을 이루 는 것은 내 인생의 신성한 목표다.는 'Achieving work-life balance is the sacred goal of my life.' 로, 도전 파라미터 5 문항 중 하나인 '나는 좌절을 극복해야 할 문제가 아니라 해결책 이 필요한 도전으로 본다.'는 'I see setbacks as "challenges" that require solutions rather than “problems” to be overcome.'으로 번역되었다.

둘째, 구인화 및 예비문항에 대해 내용타당 도를 확인하기 위해 수정델파이법을 활용하였 다. 일반적으로 개발 완료된 측정도구는 하위 요인별 3 15 문항 정도로 구성할 것을 권고 
하고 있으므로(Walsh \& Betz, 1995), 델파이 연 구 결과에 따른 문항 삭제 등 도구 수정을 고 려하여 파라미터별로 7 개씩 총 21개로 구성된 칼레이도스코프 경력태도 측정도구 예비문항 을 선정하였다. 앞서 실시한 역번역 결과로 얻은 3 개 요인 15 문항 외에, 선행연구 분석을 토대로 연구자 2 인이 상호 합의하여 요인별 2 개 문항을 추가하였다. 진정성(Authenticity) 파 라미터에 포함한 문항은 '나는 내 삶과 내 일 을 통해 진정한 나를 찾을 것이다.'와 '내가 나아갈 길에 대한 가치와 신념은 외부의 압박 에도 흔들리지 않는다.' 등 2 문항 이고, 균형 (Balance) 파라미터에는 '나에게는 가족이 가장 큰 우선순위이며, 그 다음이 일이다.', '나는 가족으로부터 얻는 행복과 일에서 얻는 성취 를 동시에 추구한다.' 등 2 문항을 포함하였으 며, 도전(Challenge) 파라미터에는 '나에게 있어 새로운 변화란 나를 성장시킬 수 있는 기회이 다.', '나는 도전적인 과제를 수행할 때 살아있 음을 느낀다.' 등 2 문항을 새로 개발하여 포함 하였다.

수정델파이 전문가 패널의 선정기준은 다음 과 같다. 먼저, 박사학위를 소지하고 있고 칼 레이도스코프 경력태도와 유관한 경력개발 또 는 진로발달 관련 변인 도구개발 경력이 있거 나 $\mathrm{HRD}$ 현업에 10 년 이상 종사한 전문가 5 인 을 선정하였으며, 측정 대상이 되는 근로자 중 박사학위를 소지하고 진정성, 균형, 도전을 경력발달 과정에서 경험했다고 응답한 경력 10 년 이상의 여성과학기술인 5인을 포함하여 총 10 인을 전문가 패널로 선정하였다. 수정델 파이는 총 2 라운드로 구성하였다. 1 라운드에 서는 전문가 패널로 하여금 파라미터에 각 문 항이 위치해 있는 것이 적절한지 타당성 정도 를 Likert 5점 척도에 응하게 하고, 개방형 질
문으로 각 문항에 대한 수정 의견을 기재하 도록 하였다. 2 라운드는 1 라운드에서 수정된 문항과 타 전문가의 코멘트, 본인의 이전 응 답 등을 종합적으로 고려하여 타당성 정도를 Likert 5점 척도에 응하게 하고, 개방형 질문으 로 각 문항에 대한 최종 의견을 기재하도록 하였다.

\section{결 과}

수정델파이 1 라운드 결과, 진정성 1 번 문항 은 번역이 어색하다는 의견 및 문장 수정 의 견에 따라 '나는 나에게 적합한 더 큰 삶의 의미를 찾길 원한다로 수정하였다. 진정성 6 번 문항 '나는 내 삶과 내 일을 통해 진정한 나를 찾을 것이다는 삶과 일이 개념적으로 '과'로 묶이는 동일한 자격이 아니라고 사료된 다는 전문가 의견과 강한 어조를 사용한 경우 점수분포가 상대적으로 낮아질 수 있어 주의 를 요한다는 전문가 의견을 반영하여 '나는 내 일을 통해 내 삶 속에서 진정한 나를 찾길 바란다로 수정하였다. 진정성 7번 문항 '내가 나아갈 길에 대한 가치와 신념은 외부의 압박 에도 흔들리지 않는다'는 '나아갈 길' 및 '외 부 압박이라는 개념이 모호하고 범위를 특정 할 수 없다는 지적에 근거하여 '내 진로에 대 한 가치와 신념은 어떠한 환경이나 조건에도 흔들리지 않는다로 수정하였다. 한편, 전문가 가 제안한 '나에게는 마음, 정신, 신체 건강이 통합된 만족감이 중요하다 는 문항을 새롭게 추가하였다.

균형 2 번 문항 '나는 항상 가족의 요구에 우선하여 나의 일을 배치한다'는 가족의 요구 에 우선하기보다는 가족 요구와 나의 일을 지 
속적으로 균형 있게 조정한다는 뜻이라고 판 단한 전문가 2 인의 의견을 반영하여 '나는 가 족의 요구를 고려하여 나의 커리어를 계획한 다' 로 수정하였다. 균형 4 번 문항 '일과 삶의
균형을 이루는 것은 내 인생의 신성한 목표 다' 는 '신성한'이라는 단어의 국내 맥락에서 의 쓰임 및 정서를 감안하여야 한다는 의견을 반영하여 '일과 가족의 균형을 이루는 것은

Table 1

Summary of the result from modified delphi analysis

\begin{tabular}{|c|c|c|c|c|c|c|c|c|c|c|c|}
\hline \multirow{2}{*}{ items } & & \multicolumn{5}{|c|}{ First Round } & \multicolumn{5}{|c|}{ Second Round } \\
\hline & & Mean & S.D. & Median & CVR & Decision & Mean & S.D. & Median & CVR & Decision \\
\hline \multirow{8}{*}{ Authenticity } & 1 & 4.10 & 0.88 & 4 & 0.40 & Modify & 4.40 & 0.70 & 5 & 0.80 & Accept \\
\hline & 2 & 4.80 & 0.42 & 5 & 1.00 & Maintain & 4.70 & 0.48 & 5 & 1.00 & Accept \\
\hline & 3 & 4.60 & 0.70 & 5 & 0.80 & Maintain & 4.80 & 0.42 & 5 & 1.00 & Accept \\
\hline & 4 & 4.20 & 0.79 & 4 & 0.60 & Modify & 4.50 & 0.71 & 5 & 0.80 & Accept \\
\hline & 5 & 4.70 & 0.48 & 5 & 1.00 & Maintain & 4.70 & 0.48 & 5 & 1.00 & Accept \\
\hline & 6 & 3.90 & 0.99 & 4 & 0.40 & Modify & 4.40 & 0.84 & 5 & 0.60 & $\begin{array}{l}\text { Modify/ } \\
\text { Accept }\end{array}$ \\
\hline & 7 & 3.70 & 1.16 & 4 & 0.20 & Modify & 4.00 & 0.94 & 4 & 0.60 & Delete \\
\hline & + & - & - & - & - & Generate & 3.10 & 1.10 & 3 & -0.40 & Delete \\
\hline \multirow{7}{*}{ Balance } & 1 & 4.20 & 0.63 & 4 & 0.80 & Maintain & 4.50 & 0.53 & 5 & 1.00 & Accept \\
\hline & 2 & 3.60 & 1.43 & 4 & -0.20 & Modify & 4.40 & 0.70 & 5 & 0.80 & Accept \\
\hline & 3 & 4.10 & 1.20 & 4 & 0.80 & Maintain & 4.30 & 0.67 & 4 & 0.80 & Accept \\
\hline & 4 & 4.50 & 1.08 & 5 & 0.60 & Modify & 4.60 & 0.70 & 5 & 0.80 & Accept \\
\hline & 5 & 3.50 & 1.45 & 4 & 0.40 & Modify & 4.30 & 0.82 & 5 & 0.60 & Accept \\
\hline & 6 & 3.10 & 1.20 & 3 & -0.20 & Delete & - & - & - & - & - \\
\hline & 7 & 4.00 & 0.82 & 4 & 0.40 & Modify & 4.60 & 0.52 & 5 & 1.00 & Accept \\
\hline \multirow{7}{*}{ Challenge } & 1 & 4.60 & 0.97 & 5 & 0.80 & Maintain & 4.90 & 0.32 & 5 & 1.00 & Accept \\
\hline & 2 & 3.90 & 1.12 & 5 & 0.40 & Modify & 4.70 & 0.48 & 5 & 1.00 & Accept \\
\hline & 3 & 4.10 & 0.99 & 4 & 0.60 & Modify & 4.20 & 0.63 & 4 & 0.80 & Accept \\
\hline & 4 & 3.90 & 1.10 & 4 & 0.20 & Modify & 4.60 & 0.70 & 5 & 0.80 & Accept \\
\hline & 5 & 4.50 & 0.71 & 5 & 0.80 & Maintain & 4.40 & 0.70 & 5 & 0.80 & Accept \\
\hline & 6 & 4.40 & 0.84 & 5 & 0.60 & Modify & 4.90 & 0.32 & 5 & 1.00 & Accept \\
\hline & 7 & 3.80 & 1.03 & 4 & 0.20 & Delete & - & - & - & - & - \\
\hline
\end{tabular}

* CVR: Content Validity Ratio 
내 인생의 중요한 목표다로 수정하였다. 균형 6번 문항은 $\mathrm{CVR}$ 값이 낮고 균형 1번 문항과 사실상 같은 의미를 내포한다는 전문가 의견 에 따라 삭제하였다.

도전 2번 문항에서 '좌절'은 전문가 의견을 바탕으로 '어려움' 으로 순화하였다. 도전 3번 문항 '추가된 업무 책임은 나에게 걱정거리가 못 된다 는 번역투가 어색하다는 다수 전문 가의 의견에 따라 '나는 기존보다 업무가 추 가되어도 크게 걱정하지 않는다'로 수정하였 다. 도전 4번 문항 '내 주위 사람들은 나를 매 우 목표 지향적인 사람이라고 설명한다.는 경 력태도 상의 도전이 지나치게 목표 지향성과 유사한 현상으로 이해될 수 있어 주의가 요구 된다는 전문가 의견에 따라 '내 주위 사람들 은 나를 목표 지향적인 사람이라고 애기한다' 로 수정하였다, 도전 7번 문항 '나는 도전적인 과제를 수행할 때 살아있음을 느낀다'는 도전 적 직무 경험과 같은 외부 변수와 중복이 우 려된다는 전문가 의견에 따라 삭제하였다.

수정델파이 2 라운드 결과, 진정성 6 번 문항 '나는 내 일을 통해 내 삶 속에서 진정한 나 를 찾길 바란다'는 '찾는다'는 동사를 '발견한 다 는 행위로 변경하면 내적인 자각, 성찰을 의미할 것이라는 의견을 반영하여 최종 '나는 일을 통해 내 삶 속에서 진정한 나를 발견하 기를 원한다로 수정 선택하였다. 진정성 7 번 문항 '내 진로에 대한 가치와 신념은 어떠한 환경이나 조건에도 흔들리지 않는다'는 칼레 이도스코프 경력태도의 경우 진로에 대한 가 치와 신념이 변한다는 전제에 기반한 개념이 므로, 진정성 문항이라 하더라도 ‘불변’의 논 리를 사용하는 것은 무리라는 전문가 의견을 반영하여 최종 삭제하였다. 진정성 8 번 문항 은 1 라운드에서 전문가 의견에 따라 문항으로
포함하였으나, 2 라운드 결과 매우 낮은 내용 타당도비율(CVR)값을 보여 최종 삭제하였다. 이에 따라, 2 라운드에 걸친 델파이 분석 결과 최종 진정성 파라미터 6문항, 균형 파라미터 6 문항, 도전 파라미터 6문항이 개발되었다.

\section{연구 2. 구인타당도 분석}

\section{연구방법}

\section{조사대상}

연구 자료 수집을 위해 온라인 조사업체에 의뢰하여 국내의 다양한 기업에 근무하고 있 는 근로자를 대상으로 온라인 설문조사를 실 시하였다. 조사 대상을 선정함에 있어 성별, 연령을 고려하여 비율표집 하였고, 기타 고 려할 수 있는 인구통계학적 요인은 무선화 (randomize)함을 원칙으로 하였다. 전체 2,857명 을 대상으로 설문지가 발송되어 476 명이 응답 을 시도하였으며(응답률 $16.7 \%$ ), 재직 근로자 가 아니거나 중간에 설문응답을 포기한 89명 을 제외한 396명의 응답자가 설문응답을 완료 하였다. 396 명 중 응답이 불성실한 43 명의 데 이터를 제외하고 최종적으로 347 명의 응답자 료를 분석하였다. 347 명의 인구통계학적 특성 은 다음과 같다. 성별은 남성이 193명(55.6\%), 여성이 154명(44.4\%)이고, 연령은 20 24세 24 명(6.9\%), 25 29세 44명(12.7\%), 30 34세 45명 (13.0\%), 35 39세 48명(13.8\%), 40 44세 43명 (12.4\%), 45 49세 47명(13.5\%), 50 54세 37명 (10.7\%), 55 59세 32명(9.2\%), 60세 이상 27명 (7.8\%)이었다. 직급은 사원급 103 명(29.7\%), 대 
리급 74 명(21.3\%), 과장급 62명(17.9\%), 차장급 32 명(9.2\%), 부장급 43 명(12.4\%), 임원 이상 33 명(9.5\%) 이었다. 학력은 박사 이상 4 명(1.2\%), 석사 24명(6.9\%), 대졸 231 명(66.6\%), 전문대졸 46명(13.3\%), 고졸이하 42명(12.1\%) 이었다.

\section{조사도구}

\section{칼레이도스코프 경력태도}

칼레이도스코프 경력태도는 연구1을 통해 내용타당도를 확보한 18 개 문항(진정성, 균형, 도전 각 6개 문항)으로 구성되었다. Sullivan과 그의 동료들(2009)이 개발한 원척도는 5점 Likert로 응답하도록 하였으나 5점 Likert에 비 해 6점 Likert 응답을 활용하는 것이 신뢰도와 변별도를 유의미하게 향상시킨다는 Chomeya (2010)의 연구결과에 따라 6점 Likert 척도(1= 전혀 동의하지 않는다. $2=$ 별로 동의하지 않는 다. $3=$ 동의하지 않는 편이다. $4=$ 동의하는 편 이다. $5=$ 동의한다. $6=$ 매우 동의한다)를 활용 하여 측정하였다.

\section{분석방법}

칼레이도스코프 경력태도의 이론적 구성개 념이 심리측정적으로 일치하는지 확인하기 위 해 통계 프로그램 IBM SPSS AMOS 25.0을 이 용하여 기술통계, 신뢰도 분석, 요인분석을 실 시하였다. 먼저 연구 1 을 통해 확인한 18 개 문항의 칼레이도스코프 경력태도 측정도구의 요인구조를 확인하기 위해 탐색적 요인분석을 실시하였다. 탐색적 요인분석은 최대우도법, 직교회전으로 추출하였으며 아이겐값을 기준 으로 요인의 수를 검토하였다. 요인부하량과 공통성을 검토하여 삭제할 문항이 있는지 확
인하였으며, 탐색적 요인분석을 통해 확인된 요인구조를 바탕으로 요인 및 문항의 구조적 관계를 검증하기 위해 확인적 요인분석을 실 시하였다. 적합도 지수는 TLI, CFI, RMSEA, SRMR을 활용하였다.

\section{결 과}

\section{탐색적 요인분석}

요인분석에 필요한 기본가정을 표본이 충족 시키는 지 확인하기 위해 $\mathrm{KMO}$ (Kaiser-MeyerOlkin) 검정과 Bartlett이 제안한 구형성 검정을 실시하였다. $\mathrm{KMO}$ 는 .921 로 1 에 근접하므로 적합하다고 보았고, Bartlett 검정값은 근사 카 이제곱 3209.433, p<.001 로 나타나 적절하므 로 요인분석의 선행조건을 만족한다고 판단하 였다. 탐색적 요인분석을 위해 고유값은 1 보 다 큰 조건으로, 베리맥스 회전을 통해 최대 우도법으로 요인을 추출한 결과 3 개의 요인 이 도출되었다(표 2 참조). 스크리도표를 함께 참고한 결과 3 요인 모형이 가장 적합한 것으 로 나타났다. 도전 파라미터의 내적 일관성 (cronbach a)은 .882, 균형은 .869, 진정성은 .832 였으며, 전체적으로는 .911 로 나타났다. 탐색 적 요인분석 결과 원 도구와 마찬가지로 3 개 의 요인 구조가 도출되었으나, 균형 1 번과 진 정성 4 번 등 일부 문항의 공통성이 4 미만으 로 나타났으며, 진정성 3번, 5번, 6번은 도전 요인에도 요인부하량이 4 이상으로 나타나 확인적 요인분석을 통해 요인구조를 재확인하 고자 하였다. 
Table 2

The result of exploratary factor analysis $(N=347)$

\begin{tabular}{|c|c|c|c|c|c|}
\hline & \multirow{2}{*}{ Items } & \multicolumn{3}{|c|}{ Factors } & \multirow{2}{*}{ communality } \\
\hline & & 1 & 2 & 3 & \\
\hline Challenge 4 & Most people would describe me as being very goal-directed. & .763 & .157 & .167 & .635 \\
\hline Challenge 5 & $\begin{array}{l}\text { I thrive on work challenges and turn work problems into } \\
\text { opportunities for change. }\end{array}$ & .714 & .266 & .246 & .642 \\
\hline Challenge 2 & $\begin{array}{l}\text { I view setbacks not as "problems" to be overcome but as } \\
\text { "challenges" that require solutions. }\end{array}$ & .687 & .201 & .314 & .611 \\
\hline Challenge 6 & For me, a new change is an opportunity to grow. & .661 & .227 & .389 & .640 \\
\hline Challenge 3 & Added work responsibilities don't worry me. & .644 & .074 & .097 & .429 \\
\hline Challenge 1 & I continually look for new challenges in everything I do. & .610 & .192 & .342 & .525 \\
\hline Balance 5 & $\begin{array}{l}\text { Nothing matters more to me right now than balancing } \\
\text { work with my family responsibilities. }\end{array}$ & .096 & .796 & .176 & .674 \\
\hline Balance 3 & $\begin{array}{l}\text { My work is meaningless if I cannot take the time to be } \\
\text { with my family. }\end{array}$ & .102 & .776 & .111 & .625 \\
\hline Balance 4 & $\begin{array}{l}\text { Achieving balance between work and family is life's holy } \\
\text { grail. }\end{array}$ & .067 & .742 & .322 & .659 \\
\hline Balance 6 & $\begin{array}{l}\text { I pursue the happiness of my family and the achievement } \\
\text { of my work at the same time. }\end{array}$ & .213 & 682 & .308 & .605 \\
\hline Balance 1 & $\begin{array}{l}\text { If necessary, I would give up my work to settle } \\
\text { problematic family issues or concerns. }\end{array}$ & .191 & .589 & .030 & .384 \\
\hline Balance 2 & I constantly arrange my work around my family needs. & .352 & .571 & -.011 & .450 \\
\hline Authenticity 2 & I hunger for greater spiritual growth in my life. & .205 & .165 & .750 & .632 \\
\hline Authenticity 1 & $\begin{array}{l}\text { I hope to find a greater purpose to my life that suits who } \\
\text { I am. }\end{array}$ & .115 & .148 & .709 & .538 \\
\hline Authenticity 4 & If I could follow my dream right now, I would. & .280 & .118 & .531 & .374 \\
\hline Authenticity 5 & $\begin{array}{l}\text { I want to have an impact and leave my signature on what } \\
\text { I accomplish in life. }\end{array}$ & .421 & .186 & .514 & .476 \\
\hline Authenticity 6 & I want to find genuine me in my life through work. & .458 & .086 & .513 & .480 \\
\hline Authenticity 3 & $\begin{array}{l}\text { I have discovered that crises in life offer perspectives in } \\
\text { ways that daily living does not. }\end{array}$ & .436 & .185 & .476 & .451 \\
\hline & Eigen Value & 3.728 & 3.293 & 2.808 & \\
\hline & $\%$ of Variance Explained: 54.607 & 20.711 & 18.296 & 15.600 & \\
\hline & Cronbach $a: .911$ & .882 & .869 & .832 & \\
\hline
\end{tabular}


확인적 요인분석

탐색적 요인분석 결과를 통해 확인된 진정 성, 균형, 도전 파라미터를 잠재변인으로 설 정하고, 측정 문항을 측정변인으로 하여 잠 재변인과 측정변인 간 경로를 연결하고 확인 적 요인분석을 실시하였다. 그 결과, 모형적 합도 측면에서 $\mathrm{X}^{2}=415.826(\mathrm{p}<.001), \mathrm{CFI}=.880$, $\mathrm{TLI}=.911, \mathrm{RMSEA}=.072[$ 하한값: .064 , 상한값: $.0801, \mathrm{SRMR}=.056$ 로 나타나 $\mathrm{X}^{2}$ 값과 $\mathrm{CFI}$ 가 적 합도 기준에 부합하지 않는 것으로 나타났 다. 이에 문항의 요인부하량과 다중상관자승 (Squared Mutilple Correlations: SMC) 값을 검토하 였다. 모든 문항의 요인부하량은 .5 이상으로 적합하였으나, 진정성1(나는 나에게 적합한 더 큰 삶의 의미를 찾기를 원한다), 진정성 4 (지금 당장 내 꿈을 따라갈 수 있다면, 나는 그렇게 할 것이다), 균형 1 (필요하다면, 나는 가족과 관 련된 문제를 해결하기 위해 일을 포기할 것이 다), 균형2(나는 가족의 요구를 고려하여 나의 커리어를 계획한다), 도전3(나는 기존에 수행 하던 업무에 추가적인 과업이 주어져도 크게 걱정하지 않는다)의 SMC 값이 .4 미만으로 나 타났다. 이에 문항을 세부적으로 검토하여 연 구자 간 합의를 통해 5 개 문항을 삭제하였다. 진정성1번 문항은 진정성 2 번 문항과 오차 상 관이 높게 나타나 두 문항 간 측정내용이 유 사하여 이를 삭제하는 것이 적절하다고 판단 하였으며, 진정성 4 번, 균형 1 번, 균형 2 번은 유연성이 낮은 우리나라 노동시장의 맥락적 특성을 고려할 때 국내 근로자의 경력 태도를 측정하기에 적합하지 않은 문항으로 판단하였 다. 마지막으로 도전 3 번 문항은 추가적인 과 업에 대한 스트레스 감내성으로 도전에 대한 다른 측정문항들과 성격이 다르다고 판단하여
삭제하였다. 문항 삭제 후 확인적 요인분석을 다시 실시한 결과 $\mathrm{x}^{2}=161.788(\mathrm{df}=62, \mathrm{p}<.001)$, $\mathrm{CFI}=.957, \mathrm{TLI}=.945, \mathrm{RMSEA}=.068$ [하한값: .055 , 상한값: .081], $\mathrm{SRMR}=.049$ 로 모형의 적합 도가 전반적으로 개선된 것으로 나타났다(표 3 참조).

\section{연구3: 교차타당도, 잠재평균차이, 준거관련 타당도 분석}

\section{연구방법}

\section{조사대상}

연구3을 위한 표본은 별도의 자료수집을 통 해 확보되었다. 연구2와 마찬가지로 2020년 7 월 기준 전체 근로자의 연령분포 비율을 확인 하여 연령별 비율 표집을 실시하였다. 온라인 전문조사업체에 의뢰하여 전체 4,456명을 대상 으로 설문지가 발송되었고 846명이 응답을 시 도하였으며(응답률 19.0\%), 재직 근로자가 아 니거나 중간에 설문응답을 포기한 212명을 제 외한 634 명의 응답자가 설문응답을 완료하였 다. 634 명 중 응답이 불성실한 3 명의 데이터 를 제외하고 최종적으로 631 명의 응답자료를 분석하였다. 631 명의 인구통계학적 특성은 다음과 같다. 성별은 남성이 347명(55.0\%), 여 성이 284(45.0\%)명이고, 연령은 20 24세 29명 (4.6\%), 25 29세 75명(11.9\%), 30 34세 82명 (13.0\%), 35 39세 88명(13.9\%), 40 44세 82명 (13.0\%), 45 49세 83명(13.2\%), 50 54세 73명 (11.6\%), 55 59세 61명(9.7\%), 60세 이상 58명 $(9.2 \%)$ 이었다. 직급은 사원급 163 명(25.8\%), 대 
리급 135 명(21.4\%), 과장급 135 명(21.4\%), 차장 급 65명(10.3\%), 부장급 84 명(13.3\%), 임원 이 상 49 명 $(7.8 \%)$ 이었다. 학력은 박사 이상 14 명 (2.2\%), 석사 65명(10.3\%), 대졸 401명(63.5\%), 전문대졸 84 명 $(13.3 \%)$, 고졸이하 67 명(10.6\%) 였다. 혼인 여부는 미혼이 234명(37.1\%), 기혼 이 385명(61.0\%) 이며, 12 명(1.9\%)은 기타(별거, 이혼, 사별)에 응답하였다.

\section{조사도구}

칼레이도스코프 경력태도는 연구 2 를 통해 도출된 13 문항을 활용하여 측정하였다. 진정 성 4문항, 균형 4 문항, 도전 5 문항으로 구성되 며, 문항은 표 3에 기술된 것과 같다.

프로티언 경력태도는 개인의 가치나 관심에 따라 자신의 경력을 자기주도적으로 개발하 고 관리하는 경력을 의미하며(Briscoe \& Hall, 2006), 가치지향성과 자기주도성의 2 가지 하위 요인으로 구성된다(Briscoe, Hall, \& Demuth, 2006). 이 연구에서는 Briscoe, Hall과 DeMuth (2006)의 측정도구를 번안한 Shin과 Jeong(2014) 의 도구를 활용하였다. 예시문항은 '내 경력의 성공과 실패에 대한 책임은 나에게 있다.'(자 기주도성), '나는 경력을 평가할 때, 임금이나 승진보다는 나의 고유한 가치를 더 추구한 다.'(가치지향성)이다. 이 연구에서 하위요인 의 신뢰도(cronbach's a)는 자기주도성 .853, 가치지향성 .838 였으며, 전체 문항의 신뢰도 (cronbach's a)는 .890 이었다.

일-삶의 균형을 측정하기 위해 Valcour(2007) 가 개발한 일-가정 균형에 대한 만족도를 측 정하는 5 문항을 활용하였다. 이 측정도구는 일과 가정 균형에 대한 전반적 만족도를 측정 하고 있으며, 국내에서는 Lee(2012)의 연구를
통해 번안된 바 있다. 예시문항은 나는 일(직 장)과 삶 두 영역에 적절히 시간을 배분하고 사용하고 있다이다. Valcour(2007)의 연구에서 신뢰도(cronbach's a)는 .93으로 보고되었고, Lee(2012)의 연구에서는 .836으로 나타났다. 이 연구에서 측정한 일-삶의 균형 5 문항의 신뢰 도(cronbach's a)는 .876이었다.

도전적 직무경험은 De Pater와 그의 동료들 (2009)이 개발한 7문항의 척도를 사용하였다. De Pater와 그의 동료들(2009)의 연구에서는 도 전적 직무경험이 하위요인이 없는 단일요인 구성개념으로 제시되었고 신뢰도는 .74로 양 호하였다. 이 연구에서는 De Pater와 그의 동 료들(2009)이 개발한 척도를 Lee와 Lee(2016)가 번역한 도전적 직무경험 7문항 척도를 활용하 였다. 예시문항은 '나는 우리 부서에서 전략적 변화를 시도하는 일을 담당한다이며 신뢰도 (cronbach's a)는 .912로 양호하였다.

주관적 경력성공은 경력만족과 고용가능성 을 각각 측정하여 합산한 값을 활용하였다. Greenhaus와 그의 동료들(1990)이 개발한 도구 를 바탕으로 Shim(2011)이 번안한 도구를 사용 하였다. 경력만족의 측정도구는 경력 전반에 대한 만족도와 목표달성, 기술과 능력, 보수, 직급 측면에서의 만족도를 묻는 5 문항으로 구 성되었으며, Shim(2011)의 연구에서 신뢰도 (cronbach's a)는 .88 이었다. 고용가능성은 Johnson(2001)이 개발한 도구를 바탕으로 Chang 과 $\operatorname{Park}(2004)$ 이 번안한 도구를 사용하였다. 고 용가능성의 측정도구는 6문항의 5점 Llkert로 측정하도록 되어있으며 Chang과 $\operatorname{Park}(2004)$ 의 연구에서 신뢰도는 .90 였다. 이 연구에서는 경 력만족과 고용가능성의 신뢰도(cronbach's a)는 각각 $.919, .881$ 이었으며, 전체 주관적 경력성 공의 신뢰도(cronbach's a)는 .917였다. 
Table 3

The result of confirmative factor analysis $(N=347)$

\begin{tabular}{|c|c|c|c|c|c|c|c|}
\hline & Path & B & $\beta$ & S.E. & $\mathrm{t}$ & AVE & $\mathrm{CR}$ \\
\hline \multicolumn{8}{|c|}{ 진정성 (Authenticity) } \\
\hline$\rightarrow$ & $\begin{array}{l}\text { 나는 내 인생에서 더 큰 정신적 성장을 갈망한다. } \\
\text { (I hunger for greater spiritual growth in my life.) }\end{array}$ & 1 & .657 & & & & \\
\hline$\rightarrow$ & $\begin{array}{l}\text { 나는 인생의 위기를 통해 새로운 관점을 얻을 수 있다는 것을 알고 있다. } \\
\text { (I have discovered that crises in life offer perspectives in ways that daily living } \\
\text { does not.) }\end{array}$ & 1.190 & .686 & .112 & $10.664^{* * * *}$ & & \\
\hline$\rightarrow$ & $\begin{array}{l}\text { 나는 스스로 성취한 것을 통해 영향력을 갖고 내 발자취를 남기고 싶다. } \\
\text { (I want to have an impact and leave my signature on what I accomplish in } \\
\text { life.) }\end{array}$ & 1.222 & .712 & .111 & $10.971^{* * *}$ & .515 & .809 \\
\hline$\rightarrow$ & $\begin{array}{l}\text { 나는 일을 통해 내 삶 속에서 진정한 나를 발견하기를 원한다. } \\
\text { (I want to find genuine me in my life through work.) }\end{array}$ & 1.213 & .717 & .110 & $11.032^{* * *}$ & & \\
\hline \multicolumn{8}{|c|}{ 균형 (Balance) } \\
\hline$\rightarrow$ & $\begin{array}{l}\text { 가족과 함께 하는 시간을 낼 수 없다면, 내 일은 무의미하다. } \\
\text { (My work is meaningless if I cannot take the time to be with my family.) }\end{array}$ & 1 & .745 & & & & \\
\hline$\rightarrow$ & $\begin{array}{l}\text { 일과 가족의 균형을 이루는 것은 내인생의 중요한 목표다. } \\
\text { (Achieving balance between work and family is life's holy grail.) }\end{array}$ & .959 & .826 & .065 & $14.783^{* * *}$ & & \\
\hline$\rightarrow$ & $\begin{array}{l}\text { 지금 당장 나의 일과 가족의 균형을 맞추는 것보다 더 중요한 것은 없다. } \\
\text { (Nothing matters more to me right now than balancing work with my family } \\
\text { responsibilities.) }\end{array}$ & .951 & .820 & .065 & $14.682^{* * *}$ & .606 & .860 \\
\hline$\rightarrow$ & $\begin{array}{l}\text { 나는 가족으로부터 얻는 행복과 일에서 얻는 성취를 동시에 추구한다. } \\
\text { (I pursue the happiness of my family and the achievement of my work at the } \\
\text { same time.) }\end{array}$ & .850 & .771 & .061 & $13.835^{* * *}$ & & \\
\hline \multicolumn{8}{|c|}{ 도전 (Challenge) } \\
\hline$\rightarrow$ & $\begin{array}{l}\text { 나는 내가 하는 모든 일에서 끊임없이 새로운 도전을 추구한다. } \\
\text { (I continually look for new challenges in everything I do.) }\end{array}$ & 1 & .720 & & & \multirow{5}{*}{.624} & \multirow{5}{*}{.892} \\
\hline$\rightarrow$ & $\begin{array}{l}\text { 나는 어려움을 극복해야 할 “문제”가 아니라 해결책이 필요한 "도전"으 } \\
\text { 로 본다. } \\
\text { (I view setbacks not as "problems" to be overcome but as "challenges" that } \\
\text { require solutions.) }\end{array}$ & 1.058 & .790 & .076 & $14.001^{* * *}$ & & \\
\hline$\rightarrow$ & $\begin{array}{l}\text { 내 주위 사람들은 나를 목표지향적인 사람이라고 애기한다. } \\
\text { (Most people would describe me as being very goal-directed.) }\end{array}$ & 1.120 & .744 & .085 & $13.205^{* * *}$ & & \\
\hline$\rightarrow$ & $\begin{array}{l}\text { 나는 업무상 어려움을 잘 극복하고, 발생된 문제는 개선의 기회로 활용 } \\
\text { 한다. } \\
\text { (I thrive on work challenges and turn work problems into opportunities for } \\
\text { change.) }\end{array}$ & 1.002 & .800 & .071 & $14.179^{* * *}$ & & \\
\hline$\rightarrow$ & $\begin{array}{l}\text { 나에게 있어 새로운 변화란 나를 성장시킬 수 있는 기회이다. } \\
\text { (For me, a new change is an opportunity to grow.) }\end{array}$ & 1.012 & .818 & .070 & $14.488^{* * *}$ & & \\
\hline
\end{tabular}

$\mathrm{X} 2=161.788(\mathrm{df}=62, \mathrm{p}<.001), \mathrm{CFI}=.957, \mathrm{TLI}=.945, \mathrm{RMSEA}=.068$ [하한값: .055 , 상한값: .081], SRMR=.049 
경력몰입은 Blau(1985)가 개발하고 Chang (1997)이 번안한 측정도구를 활용하였다. Chang (1997)가 번안한 척도 중 '나는 내가 하고 있 는 직업분야에서 내 경력을 유지하기를 원한 다 등 4문항을 활용하였다. Chang(1997)의 연 구에서 보고한 신뢰도(cronbach's a)는 .76이었 으며, 이 연구의 신뢰도(cronbach's a)는 .824였 다. 모든 측정변인은 6점 Likert 척도 $1=$ 전혀 동의하지 않는다. $2=$ 별로 동의하지 않는다. $3=$ 동의하지 않는 편이다. $4=$ 동의하는 편이다. $5=$ 동의한다. $6=$ 매우 동의한다)를 활용하여 측 정하였다.

\section{분석방법}

이 연구에서 설정한 구인 모형의 타당도를 다시 한 번 확인하기 위해 표본 2 를 대상으로 확인적 요인분석을 실시하였다. 확인적 요인 분석 모형의 적합도와 더불어 기대교차타당성 지수(Expected Cross-Validation Index; ECVI)를 확 인하였다. 또한 다집단 분석을 실시하여 남녀 기업근로자의 측정동일성을 검증하였고, 측정 오차를 통제한 상태에서 칼레이도스코프 경력 태도 평균의 성별 차이를 확인하기 위해 잠재 평균분석을 실시하였다. 마지막으로 한국판 칼레이도스코프와 관련 변인들과의 상관관계
분석을 실시하여 준거 변인들과의 관계를 확 인하였다.

\section{연구결과}

\section{교차타당도 분석 결과}

교차타당도를 확인하기 위해 연구 2 의 표본 $1(\mathrm{~N}=347)$ 을 추정표본으로 하고 연구 3 의 표본 $2(\mathrm{~N}=631)$ 를 검증표본으로 하여 모형 적합도를 비교하였다. 교차타당화집단의 모형 적합도를 살펴보면 모수추정집단과 비교했을 때 상대적 으로 양호하지 않은 것을 알 수 있으나 $\mathrm{CFI}$, TLI가 .943, .928로 양호한 수준으로 나타났으 며, RMSEA도 .072로 양호한 범위로 판단할 수 있다. 또한 교차타당성 지수(ECVI: Expected Cross-Validation Index)를 확인한 결과, 모수추정 집단은 .635 , 교차타당화집단은 .514 로 교차타 당화집단 모형이 더 안정적인 것으로 나타났 다. 즉, 표본이 달라졌음에도 불구하고 칼레이 도스코프의 3 요인 측정모형은 타당한 것으로 확인되었다.

연구 2에서 사용하지 않았던 새로운 표본 $2(\mathrm{~N}=631)$ 을 추정표본으로 하여 확인적 요인 분석을 실시하였다. 연구 2 의 결과로 제안된

Table 4

Model comparison for cross-validity analysis

\begin{tabular}{cccccccc}
\hline Model & $\mathrm{X}^{2}$ & $d f$ & $\mathrm{X}^{2} / d f$ & CFI & TLI & RMSEA & ECVI \\
\hline $\begin{array}{c}\text { Parameter Estimation Group } \\
(\mathrm{N}=347)\end{array}$ & 161.788 & 62 & $2.609^{* * *}$ & .957 & .954 & .068 & .635 \\
\hline $\begin{array}{c}\text { Cross-Validity Group } \\
(\mathrm{N}=631)\end{array}$ & 266.097 & 62 & $4.292^{* * *}$ & .943 & .928 & $\begin{array}{c}.072 \\
(.063-.081)\end{array}$ & \begin{tabular}{c}
$.5374-.740-.601)$ \\
\hline
\end{tabular} \\
\hline
\end{tabular}

${ }^{* * * *} \mathrm{p}<.001$ 
13문항 3요인 모형을 연구모형으로 설정하고 측정모형을 검증하였다. 확인적 요인분석의 적합도 지수는 $\mathrm{X}^{2}=266.097(\mathrm{df}=62, \mathrm{p}<.001)$, $\mathrm{CFI}=.943, \mathrm{TLI}=.928, \mathrm{RMSEA}=.072$ [하한값: .063 , 상한값: .081$], \mathrm{SRMR}=.045$ 로 모형의 적 합도는 양호한 것으로 나타났다. 또한 각 요 인별 표준화계수가 모두 .6 이상으로 통계적 으로 유의한 적재량을 보이고 있었으며, 다 중상관자승(SMC) 값도 .4 이상으로 나타났다. 한편, 모든 잠재 변인의 개념 신뢰도(construct reliability)가 .8 이상이었으며, 평균분산추출 (Average Variance Extracted)이 .5 이상으로 나타 나 내적 일관성 및 수렴 타당성을 확보하였다.

칼레이도스코프 측정도구의 성별에 따른 잠재 평균차이 분석

칼레이도스코프 측정도구의 3요인 모형이 남녀 재직근로자 모두에게 적용할 수 있는 모 형인지 확인하기 위해 다집단분석을 실시하였 다. 먼저 칼레이도스코프 측정도구의 3 요인
모형이 남녀 재직근로자 모두에게 적합한 모 형인지 확인하기 위해 집단 간 형태동일성을 검증하였다. 그 결과 남녀 집단 모두에서 3 요인 모형이 적합한 것으로 나타났다 $\left(\mathrm{X}^{2}=\right.$ $353.941(\mathrm{df}=124, \mathrm{p}<.001), \mathrm{CFI}=.936, \mathrm{TLI}=.920$, $\mathrm{RMSEA}=.054$ [하한값: .048 , 상한값: .061]). 형 태동일성 모형을 기저모형으로 하고 잠재변인 과 측정변인 간 경로를 제약한 측정동일성 모 형을 비교하였다. 측정요인 계수의 동일화 제 약을 가한 측정동일성 모형과 기저모형의 $\mathrm{x}^{2}$ 차이검증을 실시한 결과 기저모형(모형 A)과 측정동일성 모형(모형 $\mathrm{B}$ )간의 $\mathrm{x}^{2}$ 값의 차이는 통계적으로 유의한 것으로 나타났으나 $\left(\Delta \mathrm{x}^{2}(\Delta\right.$ $d f=18.481(10), p=.047)$, 모형 $A$ 에 비해 적합도 가 근소한 차이로 감소하였으므로 측정동일성 모형을 수용하였다. 다음으로 집단 간 측정오 차의 잔차가 동일하다고 제약한 모형 C와 측 정동일성 모형을 비교하였다. 두 모형 간 $\mathrm{x}^{2}$ 값의 차이는 통계적으로 유의하지 않았다 $\left(\Delta \mathrm{x}^{2}(\Delta d f)=20.816(13), p=.077\right)$. 따라서 모형 C 를 수용하였다. 마지막으로 집단 간 요인계

Table 5

The result of multi-group analysis between gender

\begin{tabular}{ccccccc}
\hline Model & \multicolumn{1}{c}{$\mathrm{X}^{2}(d f)$} & $\Delta \mathrm{X}^{2}(\Delta d f)$ & $\mathrm{X} 2 / d f$ & CFI & TLI & RMSEA \\
\hline Model A & $353.941(124)$ & - & $2.854^{* * *}$ & .936 & .920 & $\begin{array}{c}.054 \\
(.048-.061)\end{array}$ \\
\hline Model B & $372.422(134)$ & $18.481^{*}(10)$ & $2.779^{* * *}$ & .934 & .923 & $\begin{array}{c}.053 \\
(.047-.060)\end{array}$ \\
\hline Model C & $393.238(147)$ & $20.816(13)$ & $2.675^{* * *}$ & .932 & .928 & $\begin{array}{c}.052 \\
(.045-.058)\end{array}$ \\
\hline Model D & $414.703(153)$ & $21.466^{* *}(6)$ & $2.710^{* * *}$ & .927 & .926 & $\begin{array}{c}.052 \\
(.046-.058)\end{array}$ \\
\hline
\end{tabular}

Note: Model A: unconstrained model; Model B: constrained measurement weights; Model C: constrained measurement weights and intercepts; Model D: constrained measurement weight, intercepts, and covariance 
수 뿐 아니라 각 잠재변인의 공분산도 동일 하다고 제약한 모형을 모형 C와 비교하였다. $\mathrm{x}^{2}$ 차이검증을 실시한 결과 두 모형 간 $\mathrm{x}^{2}$ 값 은 통계적으로 유의한 것으로 나타났다 $\left(\Delta \mathrm{x}^{2}\right.$ $(\Delta d f=21.466(6), p=.002)$. 공분산까지 동일화 제약을 가한 모형 $\mathrm{D}$ 는 모형 $\mathrm{C}$ 보다 적합도가 다소 떨어지는 것을 알 수 있으나, $\mathrm{x}^{2}$ 차이검 증의 경우 사례 수에 민감하여 적합한 모형을 기각할 우려가 있으며, $\mathrm{CFI}$ 가 .01보다 적게 감 소하거나 RMSEA가 적게 증가한 경우에는 적 합도에 차이가 없는 것으로 해석할 수 있다는 주장(Chen, 2007; Cheung \& Rensvold, 2002)도 제기된 바 있다. 모형 $\mathrm{D}$ 가 모형 $\mathrm{C}$ 와 $\mathrm{x}^{2}$ 차이 검증에서 유의한 차이를 보였으나, 모형 $\mathrm{D}$ 의 적합도가 나쁘다고 해석하기에는 CFI, TLI 지 수가 .9 이상으로 양호하고, $\mathrm{CFI}$ 의 감소폭이 0.1 보다 적고, TLI와 RMSEA는 오히려 증가한 것을 고려할 때 적합도 차이가 없는 것으로 해석할 수도 있다. 따라서 성별에 따라 형태 동일성, 측정동일성, 측정오차의 잔차동일성, 공분산동일성이 모두 인정되므로 집단 간 측 정의 교차타당성이 확보되었다고 볼 수 있다.

집단 간 측정의 동일성 가정이 충족되어 두 집단 간 칼레이도스코프 하위요인의 잠재평균 비교분석을 실시하였다. 잠재평균 비교 시 두
집단 이상에서 요인의 평균을 동시에 추정할 수 없으므로 남성 근로자를 참조집단으로 하 여 하위 요인의 평균을 0 으로 고정한 뒤 여성 근로자의 하위 요인 평균을 추정하였다. 표 6 의 남녀 근로자 집단 간 잠재평균 차이분석을 살펴보면 남성에 비해 여성의 잠재평균이 상 대적으로 낮은 것을 확인할 수 있으며, 진정 성 요인에서의 차이는 유의하지 않았으나, 균 형과 도전에서의 잠재평균차이는 유의한 것으 로 나타났다. Cohen's 값을 살펴보면 균형의 경우 d값이 -.320 , 도전의 경우 -.255 로 둘 다 .20 을 넘는 것으로 나타나 중간 수준의 효과 크기를 갖는 것(Cohen, 1988)으로 확인되었다. 즉, 남성 재직근로자가 칼레이도스코프 경력 태도 중 균형과 도전을 더 높게 인식하고 있 는 것을 확인할 수 있었다. 따라서 여성이 남 성에 비해 균형에 대한 인식이 더 높을 것이 라는 가설 1 은 기각되었다.

\section{칼레이도스코프 측정도구의 준거관련타당도 분석}

칼레이도스코프의 구인타당도와 교차타당도 를 확인한 뒤 칼레이도스코프 경력태도의 총 점 및 하위요인과 관련변인 간 상관관계 분석

Table 6

The result of latent mean analysis between gender

\begin{tabular}{ccccc}
\hline Parameter & Male & Female & $\mathrm{t}$ & $\begin{array}{c}\text { Effect size } \\
\text { (Cohen's d) }\end{array}$ \\
\hline Authenticity & .00 & -.06 & -1.030 & -.015 \\
\hline Balance & .00 & -.16 & $-2.734^{* *}$ & -.320 \\
\hline Challenge & .00 & -.16 & $-2.386^{*}$ & -.255 \\
\hline${ }^{*} \mathrm{p}<.05,{ }^{* *} \mathrm{p}<.01$ & & &
\end{tabular}


을 통해 측정도구의 수렴타당도와 준거관련 타당도를 확인하였다. 먼저, 칼레이도스코프의 총점과 하위요인 간 상관관계 분석을 통해 수 렴타당도를 확인한 결과 칼레이도스코프 경력 태도 총점은 진정성과 .839, 균형과 .785, 도전 과 866 으로 높은 상관을 갖는 것으로 나타났 다. 또한 세 하위요인 간 상관관계를 살펴보 면 .444-.674의 범위를 갖고 있는 것으로 나타 나 칼레이도스코프 경력태도라는 구성개념을 측정하기 위한 내적 타당도를 갖추었다고 판 단할 수 있다.

그 다음으로 칼레이도스코프의 각 하위요인
과 유의미한 관계에 있을 것이라고 가정한 프 로티언 경력태도, 일-삶의 균형, 도전적 직무 경험, 주관적 경력성공, 경력몰입과의 상관분 석을 통해 준거관련 타당도를 확인하였다. 먼 저 자기주도성과 가치지향성의 하위요인으로 구성된 프로티언 경력태도와 칼레이도스코프 경력태도 총점과의 상관관계는 .708로 높은 수준으로 나타났으며, 특히 칼레이도스코프의 하위요인 중에서도 진정성은 자기주도성과 높 은 상관 $(\mathrm{r}=.673, \mathrm{p}<.001)$ 을 갖는 것으로 확인 되었다. 칼레이도스코프 경력태도의 총점은 일-삶의 균형 $(\mathrm{r}=.562, \mathrm{p}<.001)$, 도전적 직무경

Table 7

Correlation between kaleidoscope career attitude and related variables $(N=631)$

\begin{tabular}{|c|c|c|c|c|c|c|c|}
\hline \multirow{2}{*}{ Variables } & \multirow{2}{*}{ M } & \multirow{2}{*}{ SD } & \multicolumn{4}{|c|}{$\begin{array}{l}\text { Korean vesion of Kaleidoscope Career Attitude } \\
\text { (KKCA) }\end{array}$} & \multirow{2}{*}{$\begin{array}{c}\text { Result of } \\
\text { correlation } \\
\text { difference analysis }\end{array}$} \\
\hline & & & $\begin{array}{r}\text { Total } \\
\text { KKCA }\end{array}$ & Authenticity & Balance & Challenge & \\
\hline Total KKCA & 4.31 & 0.63 & 1 & & & & \\
\hline Authenticity & 4.44 & 0.71 & $.839^{* * *}$ & 1 & & & \\
\hline Balance & 4.35 & 0.79 & $.785^{* * *}$ & $.444^{* * *}$ & 1 & & \\
\hline Challenge & 4.15 & 0.77 & $.866^{* * *}$ & $.674^{* * *}$ & $.482^{* * *}$ & 1 & \\
\hline Protean Career Attitude & 4.22 & 0.60 & $.708^{* * *}$ & $.631^{* * *}$ & $.446^{* * *}$ & $.691^{* * *}$ & $\mathrm{~B}<\mathrm{A}, \mathrm{C}$ \\
\hline Self-directed & 4.37 & 0.62 & $.732^{* * *}$ & $.673^{* * *}$ & $.475^{* * *}$ & $.683^{* * *}$ & $\mathrm{~B}<\mathrm{A}, \mathrm{C}$ \\
\hline Value-driven & 4.07 & 0.72 & $.544^{* * *}$ & $.467^{* * *}$ & $.331^{* * *}$ & $.559^{* * *}$ & $\mathrm{~B}<\mathrm{A}<\mathrm{C}$ \\
\hline Work-life Balance & 4.20 & 0.76 & $.562^{* * *}$ & $.433^{* * *}$ & $.455^{* * *}$ & $.507^{* * *}$ & $\mathrm{~A}=\mathrm{B}=\mathrm{C}$ \\
\hline Challenging job behavior & 3.02 & 0.83 & $.481^{* * *}$ & $.353^{* * *}$ & $.298^{* * *}$ & $.546^{* * *}$ & $\mathrm{~A}=\mathrm{B}<\mathrm{C}$ \\
\hline Subjective Career Success & 3.69 & 0.81 & $.476^{* * *}$ & $.352^{* * *}$ & $.290^{* * * *}$ & $.541^{* * *}$ & $\mathrm{~A}=\mathrm{B}<\mathrm{C}$ \\
\hline Career satisfaction & 3.61 & 0.98 & $.366^{* * *}$ & $.236^{* * *}$ & $.231^{* * * *}$ & $.441^{* * *}$ & $\mathrm{~A}=\mathrm{B}<\mathrm{C}$ \\
\hline Employability & 3.78 & 0.84 & $.494^{* * *}$ & $.407^{* * *}$ & $.293^{* * *}$ & $.533^{* * *}$ & $\mathrm{~B}<\mathrm{A}<\mathrm{C}$ \\
\hline Career commitment & 3.62 & 1.00 & $.446^{* * *}$ & $.318^{* * *}$ & $.280^{* * *}$ & $.510^{* * *}$ & $\mathrm{~A}=\mathrm{B}<\mathrm{C}$ \\
\hline
\end{tabular}


험 $(\mathrm{r}=.481, \mathrm{p}<.001)$, 주관적 경력성공 $(\mathrm{r}=.476$, $\mathrm{p}<.001)$, 경력몰입 $(\mathrm{r}=.446, \mathrm{p}<.001)$ 과도 유의미 한 상관관계를 갖는 것으로 나타났다. 칼레이 도스코프 하위요인 중 도전은 도전적 직무경 험과의 상관관계가 다른 하위요인에 비해 가 장 큰 것으로 나타났으며 $(\mathrm{r}=.546, \mathrm{p}<.001)$, 균 형은 일-삶의 균형과 $\mathrm{r}=.455$ (p.<.001)로 유의 한 상관관계를 가졌다. 따라서 가설 $2,3,4,5$, 6은 모두 지지되었다.

한편, Fisher의 $\mathrm{Z}$ 변환점수를 통해 칼레이도 스코프 경력 파라미터와 관련 변인 간 상관관 계의 차이가 있는 지 분석하였다. 유의수준은 .05 에서 양측검정을 통해 통계적 유의도를 판 단하였다. 일과 삶의 균형과 칼레이도스코프 경력 하위 파라미터 간 상관관계는 유의한 차 이를 보이지 않았으나, 프로티언 경력태도와 의 상관관계에서는 균형(446)에 비해 진정성 (.631, $z=-4.667, \mathrm{p}<.000)$ 과 도전(.691, $z=-6.559$, $\mathrm{p}<.000)$ 이 유의하게 높은 것으로 나타났으며, 일 삶의 균형, 도전적 직무행동, 주관적 경력 성공, 경력몰입에서는 진정성, 균형에 비해 도 전과의 상관관계가 유의하게 높은 것을 확인 할 수 있었다. 이는 도전 파라미터에 응답값 이 높은 사람들의 경우 자신의 경력 결과를 더 긍정적으로 평가하고 경력에 보다 몰입하 고 있음을 시사한다.

\section{논 의}

이 연구의 목적은 칼레이도스코프 경력태도 의 한국판 측정도구를 개발하는 데 있다. 이 를 위해 문헌고찰, 번역-역번역 방법을 통해 마련한 칼레이도스코프 경력태도 측정도구 초 안을 수정델파이법을 통해 내용타당도를 확인
하였다. 델파이조사를 통해 수정된 문항을 설 문조사 도구로 개발, 347 명의 기업근로자를 대상으로 측정하고 탐색적 및 확인적 요인분 석을 실시하여 구성개념 타당도를 검증하였다. 마지막으로 새롭게 수집된 631명의 기업 근로 자 표본을 대상으로 칼레이도스코프 경력태도 와 관련 변인을 함께 측정하여 준거관련 타당 도를 확인하였다. 연구 결과를 통해 얻은 결 론 및 시사점은 다음과 같다.

첫째, 문화적 배경에 따라 잠재변인을 측정 하는 구체적인 행동요소들이 달라질 수 있는 데, 이 연구는 델파이, 두 차례의 표집을 통해 반복 검증하여 타당도를 확보한 도구 개발 절 차를 거친 바, 칼레이도스코프의 한국판 측정 도구를 타당화했다는 데 의의가 있다. 최근 $\mathrm{Kim}$ 과 Lee(2020)는 중소기업 초기 경력자를 대 상으로 칼레이도스코프 경력태도를 측정하여 탐색적 요인분석을 실시하고, 균형과 도전에 서 각각 한 문항씩 삭제된 도구를 활용했는데, 제거된 문항에는 이 연구에서 제거한 균형 1 번 (필요하다면, 나는 가족과 관련된 문제를 해결하기 위해 일을 포기할 것이다) 문항이 포함되어 있었다. 우리나라와 같이 노동시장 이 경직된 사회적 맥락에서는 퇴직 후 유사한 조건의 일을 구하는 것이 상대적으로 어려우 므로 해당 문항은 우리나라 문화에 적용하기 에 부적절한 것으로 판단된다. 이 연구는 정 성적 접근과 정량적 접근을 모두 활용한 통합 적 접근법(mixed method)을 바탕으로 수정델파 이법과 두 개의 표본을 통한 반복 검증을 통 해 원도구의 측정 문항 중 우리나라 기업근로 자에게 적용하기 어려운 문항을 가려냄과 동 시에 우리나라 기업근로자의 칼레이도스코프 경력태도를 측정하는 추가문항(진정성-나는 일 을 통해 내 삶 속에서 진정한 나를 발견하기 
를 원한다; 균형-나는 가족으로부터 얻는 행복 과 일에서 얻는 성취를 동시에 추구한다; 도 전-나에게 있어 새로운 변화란 나를 성장시킬 수 있는 기회이다)을 개발하고 타당도를 검증 했다는 점에서 의의가 있다. 이 연구를 통해 최종적으로 마련된 14 문항은 후속연구에서 지속적으로 연구결과를 축적할 필요가 있다.

둘째, 한국판 칼레이도스코프 경력태도를 측정하는 3 요인의 14 문항은 서로 다른 두 표 본에서도 구인타당도가 확인되었으며, 남녀 성별 집단에서도 동일한 측정도구를 활용할 수 있는 것으로 확인되었다. 칼레이도스코프 경력태도를 구성하는 진정성, 균형, 도전의 3 요인 모형은 서로 다른 표본에서도 안정적으 로 도출되었다. 한편, 칼레이도스코프 경력태 도는 개인이 생애 단계에서 어떤 경력 파라미 터를 중요하게 생각하는지를 핵심으로 하고 있으며, 세 가지 파라미터의 절대 점수보다는 3 요인 점수의 프로파일이 중요한 정보를 제공 한다. 선행연구도 이를 고려하여 알파 패턴, 베타 패턴 등으로 명명하면서 칼레이도스코프 경력 파라미터를 중심으로 판단해 왔다. 예를 들어, Sullivan과 Mainiero(2007)는 응답자 중 대 부분(84\%)의 남성들은 초기-중기-말기의 경력 단계에서 도전-진정성-균형에 각각 초점을 주 는 알파 칼레이도스코프 경력 패턴을 갖고 있 는 반면, 대부분의 여성(83\%)들은 초기에는 도 전, 중기에는 균형, 말기에는 진정성에 초점을 두는 베타 칼레이도스코프 경력 패턴을 보였 다고 보고하였다. 최근 수행된 Mainiero와 Gibson(2017)의 연구에서는 경력중기의 남녀 실업자를 대상으로 칼레이도스코프 경력태도 의 차이를 밝혔는데, 여성이 남성에 비해 균 형을 훨씬 중요하게 생각하고 있었으며, 경력 후기로 갈수록 남녀 모두 진정성을 더 강조하
는 것으로 나타났다. 이 연구에서는 진정성과 도전의 상관관계 $(r=.674)$ 에 비해 진정성과 균 형 $(r=.444)$, 도전과 균형 $(r=.482)$ 의 상관관계는 상대적으로 낮게 나타나 칼레이도스코프의 경 력 파라미터가 배타적인 양상으로 존재할 가 능성을 시사한다. 따라서 칼레이도스코프 경 력태도를 연구하고 해석하는 데 있어 칼레이 도스코프 경력태도의 프로파일을 분석하고 이 를 토대로 한 연구를 진행할 필요가 있다.

셋째, 이 연구는 칼레이도스코프 경력태도 중 균형 파라미터에서 여성이 남성에 비해 더 높은 점수를 가질 것이라 가정하였으나, 연구 결과 칼레이도스코프의 잠재평균은 남성이 여 성보다 높은 것을 밝혔다. 특히, 균형 및 도전 에서 잠재평균 차이가 유의미했으며, 균형에 서의 차이는 효과크기가 가장 큰 것으로 나타 났다. 이는 여성보다 남성들이 칼레이도스코 프의 전반적인 응답값이 상대적으로 높음을 의미하며, 여성들이 남성보다 균형을 더 강조 한다는 선행연구(Mainiero \& Gibson, 2017)와는 상반된 결과이다. Mainiero와 Gibson(2017)의 선 행연구에서 칼레이도스코프 경력태도의 성별 차이를 밝히는 데 있어 경력단계를 함께 고려 했기 때문에 이러한 차이가 나타난 것으로 판 단된다. 단순히 남녀 간 성별의 차이가 아니 라 경력단계 또는 생애발달 단계에서 주어지 는 다양한 과업과 역할 변화에 따라 성차가 존재할 수 있다는 것이다. 한국 사회에서 일 반적으로 여성에 비해 남성의 평균적인 지위, 급여수준이 높고 고용형태가 보다 안정적이라 는 것은 잘 알려진 사실이다. 칼레이도스코프 경력태도의 차이가 이러한 사회맥락적 특성 및 보편적 인식에 따른 것인지, 또는 남성이 경력과 관련하여 변화된 가치를 여성보다 용 이하게 받아들인 결과인지 확인하는 연구가 
필요하다.

넷째, 이 연구는 칼레이도스코프 경력태도 의 합산 값을 어떻게 활용할 수 있을지에 대 한 자료를 제공하고 있다는 점에서 의의가 있 다. 선행연구는 주로 칼레이도스코프 경력태 도의 경력파라미터에 따른 패턴을 분석하는데 초점을 두고 있어 전체 칼레이도스코프 경력 태도 값을 어떻게 해석할 수 있을지에 대한 근거를 제시하는 데 한계가 있었다. 이 연구 에서는 칼레이도스코프 경력태도와 관련 변인 간 상관관계를 바탕으로 칼레이도스코프 경력 태도가 보다 적응적인 경력태도와 관련되어 있을 것이라는 가설을 확인하였다. 칼레이도 스코프 경력태도는 프로티언 경력태도, 일-삶 의 균형, 도전적 직무경험과 유의미한 상관관 계를 갖는 것으로 나타났는데, 그 중에서도 전반적으로 도전 파라미터가 준거 변인들과의 상관이 높게 나타났다. 이는 도전이라는 경력 파라미터를 중요하게 생각하는 기업근로자가 자신의 경력과 관련하여 보다 긍정적인 태도 를 갖는 것으로 해석할 수 있다. 최근 경력개 발에서의 개인의 주도성을 강조하는 새로운 경력태도는 고용환경 변화의 가속화와 무관하 지 않으며, 주어진 상황에서 새로운 도전을 추구하고 주도성을 발휘해 나가는 것이 개인 의 경력개발에서도 중요한 역할을 하고 있음 을 시사한다.

연구결과를 바탕으로 칼레이도스코프 경력 태도와 관련하여 다음과 같은 연구들이 수행 될 필요가 있다. 첫째, 이 연구에서 확인한 한 국판 칼레이도스코프 경력태도를 활용하여 보 다 다양한 맥락의 근로자를 대상으로 연구할 필요가 있다. 이 연구는 우리나라의 20 대에서 60 대의 남녀 기업근로자들을 대상으로 비율 표집을 통해 표본을 구성하였다. 국외에서는
여성 $\mathrm{CEO}$, 실업자, 교사, 은퇴기 여성 등을 대 상으로 연구가 수행된 바 있다. 개인의 주도 성이 강조되는 경력 패러다임 시대의 새로운 경력태도로 지칭되는 칼레이도스코프 경력태 도가 전체 직업군에 적용될 수 있는 개념인지 다양한 표본을 통한 반복 검증 연구를 실시하 여 확인할 필요가 있다. 이러한 연구들은 칼 레이도스코프 경력태도의 개념 뿐 아니라 경 력과 관련된 변인 간 관계와 주요 메커니즘에 대한 이해도 확장시킬 수 있을 것이다. 또한, 기업, 공공기관 등 조직의 인사부서에서 경력 태도 척도를 채택하여 활용할 경우, 보직임면 장면에서 경력태도 진단 및 피드백을 통해 긍 정적인 직원경험(employee experience)을 부여할 수 있을 것이다. 특히 세 가지 경력 파라미터 와 관련하여 경력개발 개입방안을 체계적으로 구조화하여 제공할 필요가 있다. 둘째, 칼레이 도스코프 경력태도의 세대차에 대한 연구도 수행될 필요가 있다. 이 연구에서는 표집의 한계로 인해 세대차이는 다루지 않았으나, Sullivan과 그의 동료들(2009)은 X세대가 베이 비부머 세대에 비해 진정성과 균형에서 유의 하게 높은 것으로 나타났음을 보고하였다. 성 별 뿐 아니라 세대 간 집단에서 진정성, 균형, 도전과 같은 중요한 가치의 차이가 어떠한 지 확인할 필요가 있을 것이다. 마지막으로 경력 단계를 고려한 칼레이도스코프 경력태도에 대 한 연구가 이루어져야 할 것이다. 경력은 조 직 관점에서는 인적자원 차원에서 적시적소에 한정된 역량을 배치 및 활용하기 위한 매개물 로 받아들여지나, 개인 관점에서는 시간의 흐 름에 따른 역량의 발달뿐만 아니라 가족 돌봄 을 포함한 개인의 삶을 영위하는 태도 전반에 관계된 목적물이다. 일의 세계는 계속해서 변 화하고 있으며, 이에 따라 최근에 조직이 학 
습하고, 다수의 개인이 채택하는 경력태도는 다양하다. 칼레이도스코프는 세 가지 경력파 라미터의 현재 수준보다는 이러한 경력 파라 미터가 어떻게 달라지는 지에 초점을 두고 있 는 개념이므로 향후 종단 연구나 다양한 경력 단계에서의 칼레이도스코프 경력태도 인식 차 이 연구 등이 이루어져야 할 것이다.

\section{참고문헌}

Aryee, S., \& Tan, K. (1992). Antecedents and outcomes of career commitment. Journal of Vocational Behavior, 40(3), 288-305.

doi:10.1016/0001-8791(92)90052-2

August, R. A. (2010). Women's Later Life Career Development: Looking Through the Lens of the Kaleidoscope Career Model. Journal of Career Development, 38(3), 208-236. doi:10.1177/0894845310362221

Baruch, Y. (2007). The Opt-out Revolt: Why People are Leaving Companies to Create Kaleidoscope Careers. doi:10.5860/choice.44-4552

Baruch, Y., Dany, F., Pralong, J., Davense, C., Carraher, S. M., Crocitto, M. M., \& Sullivan, S. (2014). A kaleidoscope career perspective on faculty sabbaticals. Career Development International, 19(3), 295-313.

doi:10.1108/cdi-04-2013-0051

BLAU, G. J. (1985). The measurement and prediction of career commitment. Journal of Occupational Psychology, 58(4), 277-288. doi:10.1111/j.2044-8325.1985.tb00201.x

Briscoe, J. P., \& Hall, D. T. (2006). The interplay of boundaryless and protean careers:
Combinations and implications. Journal of Vocational Behavior, 69(1), 4-18.

doi:10.1016/j.jvb.2005.09.002

Briscoe, J. P., Hall, D. T., \& DeMuth, R. L. F. (2006). Protean and boundaryless careers: An empirical exploration. Journal of vocational behavior, 691), 30-47. doi:10.1108/cdi-04-2013-0051

Brislin, R. (1973). Questionnaire wording and translation. Cross-cultural research methods, 32-58.

Cabrera, E. F. (2007). Opting out and opting in: understanding the complexities of women's career transitions. Career Development International, 12(3), 218-237. doi:10.1108/13620430710745872

Chang, E. (1997). Career commitment as a complex moderator of organizational commitment and turnover intention. Korean Journal of Management, 5(2), 217-253.

Chang, E., \& Park, K. (2004). A study on the determinants affecting subjective career success. Korean Journal of Management, 12(2), 77-104.

Chen, F. F. (2007). Sensitivity of Goodness of Fit Indexes to Lack of Measurement Invariance. Structural Equation Modeling: A Multidisciplinary Journal, 14(3), 464-504. doi:10.1080/10705510701301834

Cheung, G. W., \& Rensvold, R. B. (2002). Evaluating Goodness-of-Fit Indexes for Testing Measurement Invariance. Structural Equation Modeling: A Multidisciplinary Journal, 9(2), 233-255. doi:10.1207/s15328007sem0902_5

Cho, Y., \& Lee, J. (2017). Relationship between Calling and Life Satisfaction of Volunteer Managers: Mediating Effect of Career 
Commitment. Journal of Agricultural Education and Human Resource Development, 49(2), 111-135. doi:10.23840/agehrd.2017.49.2.111

Chomeya, R. (2010). Quality of psychology test between Likert scale 5 and 6 points. Journal of Social Sciences, 6(3), 399-403. doi:10.3844/jssp.2010.399.403

De Pater, I. D., Van Vianen, A. E. M., Bechtoldt, M. N., \& Klehe, U. (2009). Employees' challenging job experiences and supervisors' evaluations of promotability. Personnel Psychology, 62, 297-325. doi:10.1111/j.1744-6570.2009.01139.x

Dyke, L. S., \& Murphy, S. A. (2006). How we define success: A qualitative study of what matters most to women and men. Sex Roles, 55(5-6), 357-371.

Elley-Brown, M. J., Pringle, J. K., \& Harris, C. (2018). Women opting in?: New perspectives on the kaleidoscope career model. Australian Journal of Career Development, 27(3), 172-180.

Fishbein, M., \& Ajzen, I. (1975). Belief, attitude, intention, and behavior. Reading MA: Addison-Wesley.

Gattiker, U. E., \& Larwood, L. (1986). Subjective career success: A study of managers and support personnel. Journal of Business and Psychology, 1(2), 78-94.

doi:10.1007/bf01018805

Greenhaus, J. H., Parasuraman, S., \& Wormley, W. M. (1990). Effects of Race on Organizational Experiences, Job Performance Evaluations, and Career Outcomes. Academy of Management Journal, 33(1), 64-86. doi: $10.5465 / 256352$
Hall, D. T. (2004). The protean career: A quarter-century journey. Journal of Vocational Behavior, 65(1), 1-13. doi:10.1016/j.jvb.2003.10.006

Johnson, C. D. (2001). In search of traditional and contemporary career success: what's an African American male to do? (Doctoral dissertation, University of Georgia).

Judge, T. A., Cable, D. M., Boudreau, J. W., \& Bretz Jr, R. D. (1995). An empirical investigation of the predictors of executive career success. Personnel psychology, 48(3), 485-519. doi:10.1111/j.1744-6570.1995.tb01767.x

Kim, C. W., \& Park, C. Y. (2008). A study on the development of a 'Work-Life Balance' scale. Journal of Leisure Studies, 5(3), 53-69.

Kim, D. Y., \& Lee, S. (2020). Relationship of Kaleidoscope career attitude, career planning and career commitment for early employees in small-medium sized enterprises: The moderated mediation effect of Kaleidoscope career attitude. Journal of Vocational Education \& Training, 23(1), 1-37.

Kim, M. K., \& Moon, J. (2020). Trends in career success research of Korea. Korean Journal of Resources Development, 21(4), 221-261. doi:10.24991/KJHRD.2018.12.21.4.221

Kim, N., \& Cha, J. (2014). Exploratory study of Korean workers' perception of career success. Andragogy Today: Interdisciplinary Journal of Adult \& Continuing Education, 17(2), 253-287.

Kirk, S. (2015). Career capital in global Kaleidoscope Careers: the role of HRM. The International Journal of Human Resource 
Management, 27(6), 681-697.

doi:10.1080/09585192.2015.1042896

Lee, H. (2012). A study on the work-life balance through multileel analysis: The effect of generational work value and supporting institutions \& climate. Unpublished doctorial dissertation, Hanyang University.

Lee, J. (2018). Identifying latent profiles based on career success perception among Korean employees: A comparison of generations $\mathrm{X}$ and Y. The Korean Journal of Human Resource Development Quarterly, 20(3), 175-203. doi:10.18211/kjhrdq.2018.20.3.007

Lee, J. M., \& Choi, H. (2019). Influence of organizational culture supporting work-life Balance on well-being and depression mediated by work-life Balance: An application of multi-group analysis across gender and age. Korean Journal of Industrial and Organizational Psychology, 32(1), 1-27 doi:10.24230/kjiop.v32i1.1-27

Lee, J., \& Cho, Y. (2019). The Systematic Review and Developing Integrated Model on the Challenging Job Experience. The Korean Journal of Human Resource Development Quarterly, 21(3), 133-163. doi: 10.18211/kjhrdq.2019.21.3.006

Lee, J., \& Lee, C. (2016). A development of integrated evaluation criteria model for measurement of career success of Korean office worker. The Korean Journal of Human Resource Development Quarterly, 18(2), 1-36.

Lee, J., \& Lee, C. (2016). The relationship of core self-evaluation and subjective career success of white-collar workers: Mediating effect of challenging job experience and moderated mediating effect of democratic characteristics. Journal of Agricultural Education and Human Resource Development, 48(1), 97-127. doi:10.23840/agehrd.2016.48.1.97

Lee, Y. G., Park, S. Y., \& Kim, J. G. (2019). Meta-analysis of domestic and international researches on protean career attitudes and outcome variables. Journal of Agricultural Education and Human Resource Development, 51(3), 21-41.

doi:10.23840/agehrd.2019.51.3.21

Mainiero, L. A., \& Gibson, D. E. (2017). The Kaleidoscope Career Model revisited: How midcareer men and women diverge on authenticity, balance, and challenge. Journal of Career Development, 45(4), 361-377. doi:10.1177/0894845317698223

Mainiero, L. A., \& Sullivan, S. E. (2005). Kaleidoscope careers: An alternate explanation for the "opt-out" revolution. Academy of Management Perspectives, 19(1), 106-123. doi:10.5465/ame.2005.15841962

Mainiero, L. A., \& Sullivan, S. E. (2006). The opt out revolt: Whe people are leaving companies to create kaleidoscope careers. Davies-Black Publishing. doi:10.5860/choice.44-4552

McCauley, C. D., Ruderman, M. N., Ohlott, P. J., \& Morrow, J. E. (1994). Assessing the developmental components of managerial jobs. Journal of Applied Psychology, 794), 544-560. doi:10.1037/0021-9010.79.4.544

Parker, B., \& Chusmir, L. H. (1992). A comparison of men and women managers' and Nonmanagers' perceptions of success. Human Resource Development Quarterly, 3(1), 73-84. 
Savickas, M. L. (2012). Life Design: A Paradigm for Career Intervention in the 21st Century. Journal of Counseling \& Development, 90(1), 13-19. doi:10.1111/j.1556-6676.2012.00002.x

Seibert, S. E., Crant, J. M., \& Kraimer, M. L. (1999). Proactive personality and career success. Journal of applied psychology, 84(3), 416-427. doi:10.5860/choice.44-4552

Shaw, S., \& Leberman, S. (2015). Using the kaleidoscope career model to analyze female CEOs' experiences in sport organizations. Gender in Management: An International Journal, 3a6), 500-515. doi:10.1108/gm-12-2014-0108

Shim, M. (2011). The protean career orientation and career success: The role of career development. Unpublished doctorial dissertation, Korea University.

Shin, S., \& Jeong, J. (2014). The Causal Relationships among Subjective Career Success,Job Security, Organizational Career Management Support, Protean Career Attitude, and Protean Career Management Behavior of the Workers in Major Industries, Korea. Journal of Agricultural Education and Human Resource Development, 46(2), 183-213. doi:10.23840/agehrd.2014.46.2.183

Sullivan, S. E., \& Baruch, Y. (2009). Advances in Career Theory and Research: A Critical Review and Agenda for Future Exploration. Journal of Management, 35(6), 1542-1571. doi:10.1177/0149206309350082
Sullivan, S. E., \& Mainiero, L. A. (2007). The changing nature of gender roles, alpha/beta careers and work life issues. Career Development International, 12(3), 238-263. doi:10.1108/13620430710745881

Sullivan, S. E., Forret, M. L., Carraher, S. M., \& Mainiero, L. A. (2009). Using the kaleidoscope career model to examine generational differences in work attitudes. Career Development International, 14(3), 284-302. doi:10.1108/13620430910966442

Sullivan, S. E., Forret, M. L., Mainiero, L. A., \& Terjesen, S. (2007). What motivates entrepreneurs? An exploratory study of the kaleidoscope career model and entrepreneurship. Journal of Applied Management and Entrepreneurship, 12(4), 4-19. doi:10.1108/13620430910966442

Valcour, M. (2007). Work-based resources as moderators of the relationship between work hours and satisfaction with work-family balance. Journal of Applied Psychology, 92(6), 1512-1523. doi:10.1037/0021-9010.92.6.1512

Walsh, W. B., \& Betz, N. E. (1995). Tests and assessment. Prentice-Hall, Inc.

투고일자 : 2020. 10. 19 수정일자 : 2020. 12. 01 확정일자 : 2020. 12. 15 


\section{Validation for Korean Version of Kaleidoscope Career Attitude Measurement}

\author{
JaeEun Lee \\ Sangji University
}

\section{BoYoung Jung $^{\dagger}$}

Hyundai Motor Company

The purpose of this study is to validate the Kaleidoscope career attitude scale developed by Sullivan et al. (2009) to measure the new career attitudes of Korean corporate employees. This study can be summarized as follows: first, the Korean version of the Kaleidoscope career attitude measurement's psychometric equivalence and contents validity was verified. Second, the Kaleidoscope career attitude measurement items consisted of three factors, equivalent to the original scale. Third, the fit of the measurement model consisting of 13 items was confirmed with the new sample. And it was confirmed that the same scale could be used in the male and female groups. Fourth, the difference in the latent mean was significant in balance and challenge parameters. Comprehensive research results revealed that the Korean version of the Kaleidoscope career attitude is valid and reliable. Based on this result, the significance and limitations of the research and suggestions for future research were discussed.

Key words : Kaleidoscope Career Model(KCM), Career Attitude, Measurement, Validation, Latent Mean Analysis

* This work was supported by the Ministry of Education of the Republic of Korea and the National Research Foundation of Korea(NRF-2019S1A5A8038225).

† Corresponding Author: Boyoung Jung, Senior Manager, HRD Team, byjung@hyundai.com 